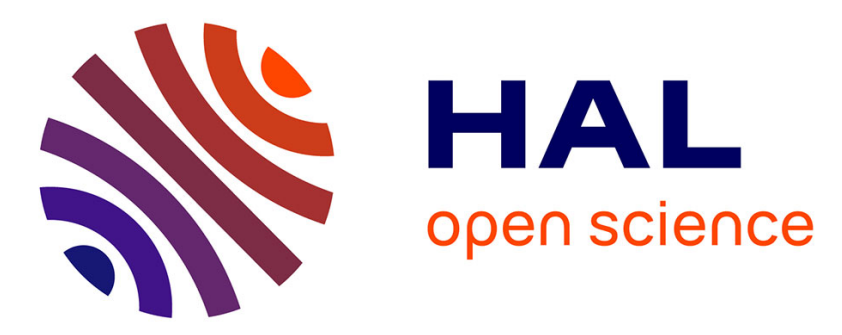

\title{
Do workers make good neighbours? The impact of local employment on young male and female entrants to the labour market
}

\author{
Matthieu Solignac, Masime Tô
}

\section{- To cite this version:}

Matthieu Solignac, Masime Tô. Do workers make good neighbours? The impact of local employment on young male and female entrants to the labour market. Annales d'Economie et de Statistique, 2018, 130, pp.167-198. 10.15609/annaeconstat2009.130.0167 . halshs-02005549

\section{HAL Id: halshs-02005549}

https://shs.hal.science/halshs-02005549

Submitted on 27 Mar 2019

HAL is a multi-disciplinary open access archive for the deposit and dissemination of scientific research documents, whether they are published or not. The documents may come from teaching and research institutions in France or abroad, or from public or private research centers.
L'archive ouverte pluridisciplinaire HAL, est destinée au dépôt et à la diffusion de documents scientifiques de niveau recherche, publiés ou non, émanant des établissements d'enseignement et de recherche français ou étrangers, des laboratoires publics ou privés. 


\title{
Do Workers Make Good Neighbours?
}

\section{The Impact of Local Employment on Young Male and Female Entrants to the Labour Market*}

\author{
Matthieu Solignac ${ }^{\dagger} \quad$ Maxime Tô $\hat{o}^{\ddagger}$
}

\begin{abstract}
June 2018
Abstract

This paper investigates the social endogenous effect linking the employment probability of young workers entering the labour market to the local employment rate. We focus on the transition from school to work, using a representative sample of youths leaving the French educational system in 1998 and 2004. We identify the causal effect of local employment rate using a neighbourhood fixed-effect strategy (Bayer et al. (2007)). We provide evidence that the within-neighbourhood random allocation assumption is likely to hold. The results show that an individual's own employment is strongly affected by the share of working people in their neighbourhood, estimates being higher for high-school dropouts. Results also reveal gender differences, suggesting that young people are more sensitive to same-sex neighbours.
\end{abstract}

Keywords: Neighbourhood effects, Local social interactions, Unemployment, Female employment; JEL Classification: R23, J60, C31, J16

\footnotetext{
${ }^{*}$ We are grateful to participants at RES conference (Manchester), ERSA (St-Petersburg), JMA (Clermont-Ferrand), AFSE (Aixen-Provence), RUES (Paris), TEPP Conference (Nantes), CTN Workshop (Coventry), LEDi Workshop (Dijon), CREM Summer School (Rennes), AMSE-Greqam Joint Seminar (Aix-Marseille), and in particular to Yann Bramoullé, Mathieu Bunel, PierrePhilippe Combes, Camille Hémet, Laurent Gobillon, Florence Goffette-Nagot, Roland Rathelot, Marc Sangnier, Grigorios Spanos and Yves Zénou, as well as the anonymous referees for their useful comments and discussions. Céreq and SG-CIV coordinated a working group to exploit newly introduced geolocation data in the Céreq Génération surveys. Our thanks go to the organizers and members of the analysis group, in particular Romain Aeberhardt, Anthony Briant, Thomas Couppié, Céline Gasquet, Thierry Kamionka. Matthieu Solignac gratefully acknowledges financial support from the French State in the framework of the "Investments for the future" programs IdEx Bordeaux, reference ANR-10-IDEX-03-02, and LabEx iPOPs, reference ANR-10-LABX-0089, as well as from the Nouvelle Aquitaine region. Maxime Tô acknowledges financial support from the ERC (MicroConLab) and also from the ESRC through the Center for the Microeconomic Analysis of Public Policy at IFS.

${ }^{\dagger}$ Univ. Bordeaux, CNRS, Comptrasec, UMR 5114, F-33608 Pessac, France; Institut national d'études démographiques (INED), F-75020 Paris, France; University of Pennsylvania, Population Studies Center, PA-19104 Philadelphia, USA. E-mail: matthieu. solignac@u-bordeaux.fr

${ }^{\ddagger}$ University College of London (UCL) and Institute for Fiscal Studies (IFS), 10 Gordon Street, London, WC1H 0AX, UK. E-mail: maxime.to@ucl.ac.uk (corresponding author)
} 


\section{Introduction}

The sharp increase in youth unemployment in Europe stands among the main lasting consequences of the 2008 financial crisis. Over the past seven years, young people have been the hardest hit by the job crisis and their unemployment rate remains at crisis peak levels, becoming a major political issue (International Labor Organization (2012)). Even though the youth unemployment rate started to decrease in 2013 in most European countries, it has not recovered to its pre-recession level (Eurostat (2016)): 22\% of 15-24 years olds were still unemployed in the Euro area in 2015, which is twice the rate of unemployment observed for the whole working-age population. This is all the more worrying as early unemployment spells have long-term career

effects on earnings and employment (Arulampalam et al. (2000), Gregg (2001), Oreopoulos et al. (2012), Altonji et al. (2014)).

In France, the youth unemployment rate between 15 and 24 years old has been at least twice the average rate for the last 30 years (Cahuc et al. (2013), INSEE (2016)), and it remains a constant concern for public agencies. But beyond the national average, youth unemployment varies widely across the country: in 1999, its rate was below $11 \%$ in the first decile of the neighbourhood while it was above $42 \%$ in the tenth one. This inter-decile range for the youth population is twice as high as the one observed for the entire working-age population (Solignac and Tô (2016)).

The difficulties faced by youths from deprived urban suburbs in the labour market are well-documented, and it is widely accepted that living in these neighbourhoods has a negative impact on getting a job. However, there is a debate over the mechanisms explaining how spatial location can affect individual success. Social and ethnic segregation suggests the existence of geographical sorting of workers with respect to their job prospects. Physical and social disconnection of the neighbourhood from job opportunities can also generate spatial mismatch (Kain (1968), Gobillon and Selod (2014)) and statistical discrimination such as redlining (Zenou and Boccard (2000)), and then affect the probability of getting a job (Ioannides and Loury (2004)). Last but not least, the employment situation of immediate neighbours may play a decisive role in the process of getting a job. By spreading information about job openings, or referring people to potential employers, networks and their spatial dimension can generate endogenous social effects (Bayer et al. (2007)). Pressure toward conformity or emulation inside the neighbourhood would also generate spillover effects (Bernheim (1994)). Immediate neighbours may thus play a decisive role in the process of getting a job as most young people 
remain in the neighbourhood they grew-up in, and they cannot rely on other networks such as actual or former colleagues (Calvo-Armengol and Jackson (2004)).

This paper investigates the social endogenous effect (Manski (1993), Brock and Durlauf; Brock and Durlauf $(2001 ; 2007))$ linking the employment probability of young workers entering the labour market to the local employment rate. To disentangle this effect from the other effects previously described, we use the 1998 and 2004 Génération surveys ${ }^{1}$ that link a cohort of individuals entering the labour market to their place of residence at the moment they leave school. This information allows us to identify the precise block-group individuals are living in, and where social interactions are supposed to take place. Given that these block-groups are nested in neighbourhoods that are fairly homogeneous, we use a neighbourhood fixed-effect strategy to disentangle the endogenous social effect from any sorting pattern, and to control for any spatial mismatch effect.

This identification strategy is similar to the one used by Bayer et al. (2007), and was already applied in a French context by Solignac and Tô (2016). Here, we contribute to the literature by providing new evidence about the validity of the strategy in the French context. We also provide new results showing the different impact of the local context on the labour market transitions for men and women. Our general finding is that social interactions matter for transitions from school to work: a one percentage point higher value of the local level of employment significantly increases the chance of getting a job by 0.09 to 0.14 percentage point. The employment situation of people in the neighbourhood has a direct effect on finding a job. However, it must be highlighted that the magnitude of this effect varies depending on individual characteristics. In particular, high-school dropouts are more likely to be influenced by the local context. In general, we find stronger effects for sub-populations that are expected to rely more on their neighbours to find a job, which reinforce the confidence in our identification strategy. Results also reveal interesting gender differences: we find that men are much more sensitive to the male employment rate, and women to the female employment rate.

The rest of the paper proceeds as follows. Section 2 reviews the previous findings in the literature showing how social interactions and residential location could affect labour market integration of young people. Section 3 presents the identification strategy. Section 4 provides

\footnotetext{
${ }^{1}$ The 1998 and 2004 Génération survey is a nationally representative sample of 60,000 youths leaving the French educational system in 1998 and 2004. It is collected by Céreq (the French Centre for Research on Education and Employment). This article is, alongside Aeberhardt et al. (2015), Kamionka and Ngoc (2016), and Solignac and Tô (2016), one of the first to take advantage of the detailed geographic information recently added to these two data bases.
} 
an overview of the data, it defines the geographic partitions used, shows why this particular partition is relevant regarding our identification strategy, and how we combine Génération databases with census data to implement estimation. Section 5 presents the results carried out for men and women living in urban neighbourhoods. It highlights the robustness of the effect, and also its heterogeneity according to individual characteristics. The final section concludes.

\section{Neighbourhood Effect on Labour Market Outcomes for Men and Women}

As stated by Ioannides and Topa (2010), individuals can "affect each other's decisions, preferences, information sets and outcomes, directly rather than indirectly through markets". Over the past few years, a growing literature in economics analyses demonstrates the importance of these "social interactions" on individual behaviour (Akerlof, 1997) especially between people that are spatially close like neighbours (Ioannides and Topa (2010), Özgür (2011), Topa and Zenou (2015)). This literature shows that social interactions between individuals living in the same area directly affect many dimensions of their life such as education (Goux and Maurin, 2007), consumption (Grinblatt et al., 2008), housing (Ioannides, 2011), and employment (Bayer et al., 2008).

Among the different categories of individuals, young people have been shown to be particularly sensitive to the local influence (Crane, 1991). Given that they can rarely rely on a professional network when they leave the educational system, they often get a job through the decisive role of personal contacts such as friends or family members (Holzer (1988), Ioannides and Topa (2010), Kramarz and Skans (2014)). This explains why family members, friends and more generally acquaintances can have such a decisive role in getting their first job. All these types of interpersonal ties might provide an access to a job offer that fits the profile and the expectations of the newcomer in the labour market. Granovetter (1973) highlights the key role of potential weak ties in this process: an acquaintance can bridge the gap between unconnected networks. The impact of social interaction in finding a job is not restricted to the closest friends or family members: acquaintances might have a similar or even a bigger role.

Residential neighbourhood determines a major part of the social interactions for youths. Most of their interpersonal relationships developed in the neighbourhood where they grew-up in, and where most of them still live. In particular, the residential location of their parents 
determines their school attendance zone and many of their friends. Thus residential neighbourhood may play a key role in defining the spatial dimension of social interactions (Patacchini et al., 2015): the network of an individual relies heavily on their neighbours, especially if they neither went to college nor started to work.

The close link between individual employment situation and the one of close neighbours has also been investigated, highlighting several underlying interactions that can generate social effects. First, the fact that neighbours have a job can favour the circulation of information between the neighbourhood and the labour market. Employed people can bring back information about the labour market in their neighbourhood, and potentially spread information about job openings (Ioannides and Loury, 2004). Conversely, people having a job can also send back signals to the labour market by referring their close neighbours to potential employers (Andersson et al. (2014), Hellerstein et al.; Hellerstein et al. (2011; 2014)). Second, the local employment situation can set up a social norm and then the conformity to social norm can affect the intensity of the job search (Bernheim, 1994). The higher the level of employment in the neighbourhood, the stronger the stigma surrounding remaining unemployed (Clark (2003), Stutzer and Lalive (2004)). The fact that former schoolmates already have a job can generate peer pressure or emulation. Older people in the neighbourhood can also be considered as role models (Mota et al., 2016) by youth who are then inclined to imitate them.

Neighbours may not only affect job prospects but also the decision to work. In particular, the labour supply of a woman may depend on the employment situation of similar women living in her close neighbourhood. Recent papers (Mota et al. (2016), Nicoletti et al. (2016)) investigate these effects and find that neighbours actually affect womens' decision to work, especially those who share similar demographic characteristics (for France, see Maurin and Moschion (2009)). Mota et al. (2016) highlight the specific effect of neighbourhood peers on the labour supply of women. Working women with similar age children could be seen as role-model by the women living in their close neighbourhood and as a source of information ${ }^{2}$. Thus, peer-effects could be gender specific: women could be mainly affected by women, while men could be affected be men. However, the lower elasticity of male labour supply could lower peer effects estimated for men.

These local social interactions can be embedded in other types of neighbourhood effects. Indeed the reputation of the neighbourhood or its physical distance from places of work can also

\footnotetext{
${ }^{2}$ See Nicoletti et al. (2016) for a detailed review of the potential mechanisms, especially those related to mothers
} 
affect the probability of getting a job for people living in the same area. In the hiring process, incomplete information about the candidates might lead employers to judge their suitability based on the reputation of the place where they live, and to infer the applicant's quality by the average characteristics of the population living in this area (Arrow, 1973). For example, employers might be reluctant to hire someone coming from an area where crime rates are high ("redlining effects", Zenou and Boccard (2000)). The disconnection from jobs can also be more physical than social: the spatial mismatch hypothesis introduced by Kain (1968), and more recently reviewed in Kain (2004), states that the distance between residential and job locations affects the probability of getting a job. Various mechanisms, listed by Gobillon et al. (2007, 2014), can produce such an effect, such as higher transportation costs. Thus, efficiency and intensity of the job search can be affected by the distance from job opportunities. Employers might also be reluctant to hire candidate living too far away from the place of work: they may fear that such an employee will arrive late more often, or that they will be less productive because of the fatigue due to commuting time.

Additionally, similar behaviour by individuals living in the same area might simply be due to spatial sorting of individuals. Given the spatial segregation observed on individual characteristics like socio-economic categories and ethnic origin, there may also be sorting on unobserved capacity to get a job. Thus measuring the effect of social interactions on labour market transitions requires the use of specific econometric strategies to control for such sorting patterns. Various strategies have been implemented to address these effects ${ }^{3}$ : structural modelling of location choices (Dahl, 2002), quasi-natural experiments based on population for whom location is constrained (by their parents for youth (Ihlanfeldt and Sjoquist, 1991) or by public authorities for refugees (Damm, 2014)), instrumental variable approach of the local level of employment or inference of the magnitude of selection bias (Dujardin and Goffette-Nagot, 2010), individual (Weinberg et al., 2004) or spatial (Bayer et al., 2008) fixed effects. In French studies, the effect of the local level of employment is not always conclusive. Sari (2012) finds that living in Paris' deprived suburbs (where unemployment is 7.5 points higher) reduces the probability of getting a job by 6 points. Dujardin and Goffette-Nagot (2010) initially find that living in Lyon's deprived neighbourhoods would increase by 2.1 points the probability to be unemployed, but this effect disappears when controlling for potential sorting.

\footnotetext{
${ }^{3}$ See Topa and Zenou (2015) for a recent survey
} 


\section{Identification and Empirical Model}

We aim to identify the importance of social interactions on individuals' transitions from school to work, i.e. the impact of close neighbours employment status on young entrants' ones. The neighbours we consider are the ones living close to the place where individuals were living in when they left the educational system, and individuals' outcomes are measured three years after that time, regardless of the place they end up living in. The residential context is thus predetermined with respect to the entry on the job market, which rules out the existence of potential reflection problem mentioned by Manski (1993). Indeed, we consider that the local social equilibrium is already reached when the individual enters the labour market, and that new entrants on the labour market do not influence it. There are too few entering at a time in comparison with the local labour force. The binary model we consider also provides identification power given the non-linearity linking individual behaviour to the behaviour of the group he belongs to (see Brock and Durlauf; Brock and Durlauf $(2001 ; 2007)$ ).

However, the direct observation of local employment and labour market transitions is insufficient to identify social interactions from contextual effects and spatial sorting patterns. Young entrants to the labour market may have the same trajectories as their neighbours because of the similar local labour market conditions they face, or simply because they are similar. In order to deal with this endogeneity issue, we propose to identify the causal effect using within neighbourhood variation of the local employment rate.

This identification strategy is inspired by Bayer et al. (2008). Using data from Boston metropolitan area, they take the distribution of individuals into a Census block as random within a given neighbourhood. This approach has already been adopted in the French context by Solignac and Tô (2016) and Hémet and Malgouyres (2016). In that strategy, we distinguish the precise block-group ("IRIS") ${ }^{4}$ where individuals are living from neighbourhoods ("Grands quartiers") $)^{5}$. We make the assumption that social interactions take place at the block-group level (IRIS), and we assess the effect of local employment rate on individual trajectories at this level.

Identification relies on the fact that within neighbourhoods, individuals unobserved hetero-

\footnotetext{
${ }^{4}$ IRIS in French meaning "aggregated units for statistical information" Its formal definition can be found on the website of the French National Institute of Statistics (INSEE): http://www.insee.fr/en/methodes/ default.asp?page=definitions/iris.htm. It corresponds to the smallest geographical unit we use and its characteristics are discussed later in the article.

${ }^{5}$ A neighbourhood ("Grand quartier") is defined "as a grouping of several adjoining statistical group of blocks within the same municipality."
} 
geneity is not correlated with the residual variation of the local employment rate. In other words, in a given neighbourhood and conditional on their observed characteristics, individuals have to be randomly assigned between groups of blocks. This hypothesis is likely to be verified since individuals may choose the neighbourhood they live in, but conditional on that choice, the precise group of blocks they end up living in is subject to randomness. This identification strategy will also allow us to disentangle the social effect from spatial mismatch. Indeed, two individuals living in the same neighbourhood share the same residential environment. Distance to jobs is the same, and they have access to the same amenities. Their place of residence being labelled and known under a similar name, firms can hardly make any distinction between the residential location of these applicants, which rules out redlining effect from possible interpretations of the results. The key assumption is that inhabitants of a block-group do not differentiate themselves from the other blocks of the same neighbourhood.

To formalize our identification strategy, let $Z_{i}$ be a vector of individual observed characteristics at the moment individual $i$ leaves school, $E_{i}$ the variable denoting individual employment status three years later, and $\varepsilon_{i}$ the unobserved capacity of getting a job. When leaving school, this individual lives in block-group $b(i)$, that belongs to neighbourhood $n$. Employment is thus:

$$
E_{i}=1\left\{Z_{i} \beta+X_{n b(i)} \gamma+\varepsilon_{i}>0\right\}
$$

where $X_{n b(i)}$ is the employment rate in block-group $b(i)$ of neighbourhood $n$. To illustrate the potential endogeneity of the block-group employment rate, $X_{n b}$ is supposed to be the result of two independent factors: a neighbourhood factor $\varphi_{n}$, and a residual block-group factor $\nu_{n b}$ :

$$
X_{n b}=\varphi_{n}+\nu_{n b}
$$

Our framework allows for any correlation between the neighbourhood component $\varphi_{n}$ and individual unobserved heterogeneity $\varepsilon_{i}$, but we make the assumption that the block-group residual variation $\nu_{n b}$ is independent from $\varepsilon_{i}$, so we estimate the employment equation 1 using a fixedeffect approach that cancels out the $\varphi_{n}$ component. Given that we are dealing with a binary outcome, and that including neighbourhood fixed-effect would expose us to the usual incidental parameter issue (Lancaster (2000)), we estimate $\beta$ and $\gamma$ parameters through a conditional logit model (Chamberlain (1980)). 


\section{Data}

\subsection{Génération Surveys and Census Data}

Estimations are conducted on the Génération surveys carried out by Céreq ${ }^{6}$. These surveys are representative samples of young people leaving the French educational system for the first time in a given year. These young workers are interviewed three years after they left school. In addition to information relative to their labour market situation, the Génération surveys include many of the respondent's characteristics: family's socioeconomic status, age, education, household situation, parents' place of birth and nationality at birth, etc. In order to have a larger estimation sample, we use the 2001 and 2007 surveys relative to the 1998 and 2004 cohorts, respectively.

In our analysis, we focus on the employment situation of individuals when they were interviewed, three years after leaving school. We relate this situation to the context of their residential location at the moment they left school in 1998 and 2004 according to the wave of the survey we consider. If individual labour market situations are measured from the surveys previously described, local employment rates are measured from the census. The 1999 census is matched to the 2001 survey and the 2006 census to the 2007 survey. $^{7}$

We focus on two distinct measurements for the local employment situation. First, we use the employment-population ratio (EPR), which is obtained as the ratio between employed people and the total population where the individual is living. The second variable is the employment rate (ER), i.e. the ratio between working individuals over the workforce. The former ratio provides information on the probability to encounter people having a job in the neighbourhood. It reflects not only the level of unemployment among the workforce but also participation in the job market itself. If women are more prone to staying away from the job market, this ratio might be the more relevant one to study their probability to have a job. The latter ratio is restricted to the subsample of labour force, focusing on the proportion of them having a job. Such a restriction may be useful when considering the high proportion of young people who are still at school. ${ }^{8}$ People who already entered the job market might be the

\footnotetext{
${ }^{6}$ French Center for Research on Education, Training and Employment

${ }^{7}$ Since 2004 , the census is based on annual collection that cover the whole territory in 5 years. The data published for the reference year 2006 gather data collected in 2004-2008 (Godinot (2014)).

${ }^{8}$ Contrary to the Generation survey, data from the Census include all individuals irrespective of their school attendance. Thus, the EPR is lowered by the proportion of individuals who are still at school and did not enter yet the job market.
} 
subgroup of peers which really matters to get a job.

In order to get the average employment situation of the most relevant group that could help individuals to get a job, we use these ratios for different age groups, namely people aged 15 to 24 , and people aged 25 to 64 years old. It is not clear whether young people would be a better channel to get a job than older people. Considering our population of interest, the younger age group may be a better approximation of peers, while the older one may have stronger links with the labour market and the decision-making process for hiring. We also stratify these rates by gender, following in that the distinction made by Mota et al. (2016) among neighbours sharing similar demographic characteristics or not. Their idea is that the participation of women in the labour force might depend above all on the participation of other women rather than on the global employment rate of men and women combined.

\subsection{Geographical Partition}

\subsubsection{Block-groups and Neighbourhoods}

Our identification strategy is closely linked to the geographical partition of the territory. So we start by giving a detailed description of it. Census block-groups (IRIS) ${ }^{9}$ are defined by the French National Institute of Statistics (INSEE) to be "homogeneous in terms of living environment, and the boundaries of the unit are based on the major dividing lines provided by the urban fabric (main roads, railways, bodies of water etc.)". They are the smallest geographic units used by INSEE for most of their local data. About 1,800 urban municipalities in mainland France are divided into census block-groups. The total number of census block-groups is slightly higher than 16,000. Block-groups are nested in neighbourhoods ${ }^{10}$ that aggregate several contiguous block-groups within municipalities. These larger areas are also defined so that each unit is homogeneous. Neighbourhoods are generally known under a specific name that is often used in everyday life. Note that small municipality may only be divided in block-groups, in which case, we consider the whole municipality as a unique neighbourhood. French block-groups are larger units than the one used by Bayer et al. (2008), but their frontiers are determined to preserve homogeneity. ${ }^{11}$ The advantages of this partition in terms of homogeneity and size

\footnotetext{
${ }^{9}$ In the following of the paper, we use the denomination "group of blocks" or "block-group" to name "IRIS" divisions.

10 "Grands quartiers" in the French denomination

${ }^{11}$ Whereas the structure of neighbourhood specific to US cities might affect the homogeneity of the blocks (Duncan and Duncan (1955)).
} 
have been pointed out by Briant et al. (2015). A detailed analysis of the homogeneity of the neighbourhoods ("Grands quartiers") is presented later in the text.

As a case in point, we can highlight an urban area like Paris, which is populated by more than 13 million inhabitants, is made up of around 1,800 municipalities. The city of Paris (Paris inner city) corresponds to the 20 central municipalities. One municipality like the " $20^{\text {th }}$ arrondissement" (Fig. 1a) was populated by 182,952 individuals in 1999 living in a $5.98 \mathrm{~km}^{2}$ area. It is divided into 4 neighbourhoods (areas delineated in dark bold lines), each of them being divided into 14 to 26 census block-groups (smallest units in lighter grey dotted lines on Fig. 1a). Thus, the dimension of this municipality can be approximately represented as a 2 by $3 \mathrm{~km}$ rectangle, and census block-groups as geographical units that in the worst case are not longer than three hundred meters. Other cities of different sizes are presented on Figure 1 in order to give an idea of the size of neighbourhoods and block-groups.

\subsubsection{Homogeneity of Neighbourhoods}

The key assumption of our identification strategy is that in a given neighbourhood ("Grand quartier"), young entrants in the labour market are randomly distributed between block-groups conditional on their observed characteristics. Although this assumption cannot be directly tested, we can show from the census that within neighbourhoods, the between block-groups distribution of the population observed characteristics is not subject to systematic spatial autocorrelation. To do so, we compute Moran indices. ${ }^{12}$ For a given characteristic of block-groups such autocorrelation indices will be large and positive if block-groups with similar characteristics tend to be close, and closer to zero if spatial units are randomly spread out. Although this is not a sufficient nor a necessary condition to test the validity our identification strategy, it suggests that sorting is limited within neighbourhood, compared to larger area, which supports our strategy.

From the 1999 census, we compute the Moran indices for a set of characteristics of blockgroups (including age distribution, education, origin, and several employment rates and employment population ratios) at different geographical levels: urban unit level ("Unité Urbaines") ${ }^{13}$, municipality level, and neighbourhood level ("Grand quartier").

\footnotetext{
${ }^{12}$ More details are provided in appendix A.

${ }^{13}$ According to the INSEE, "the notion of urban unit is based on the continuity of built up land mass and the number of inhabitants. We call urban unity a municipality or a group of municipalities which includes a continuously built up zone (no cut of more than 200 meters between two constructions) and at least 2,000 inhabitants."
} 
Figure 1: Block-groups ("IRIS") and Neigbourhoods ("Grands quartiers") Illustrative Maps

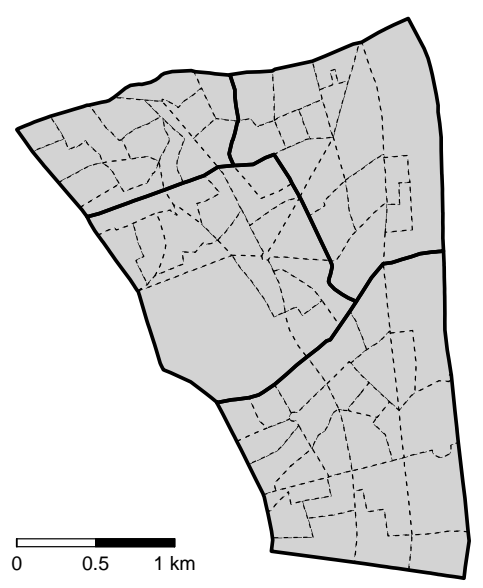

(c) Lens (Pop.: 36,206)

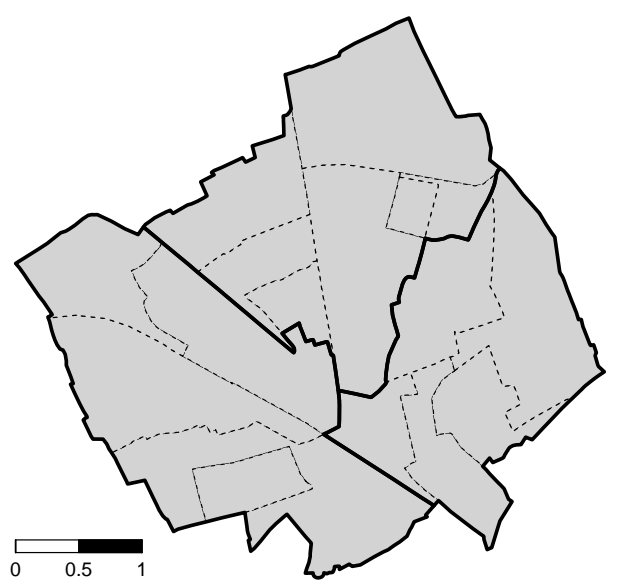

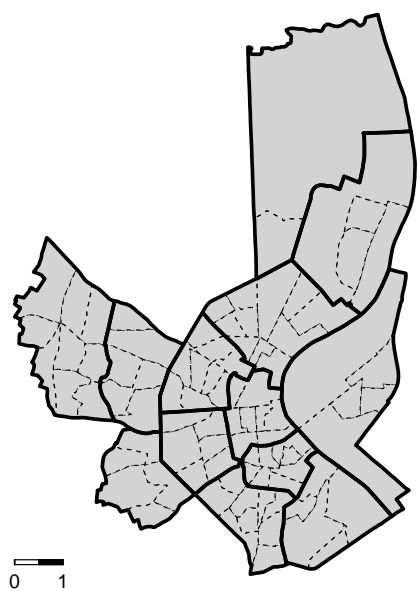

(d) Villeurbanne (Pop.: 124,215)

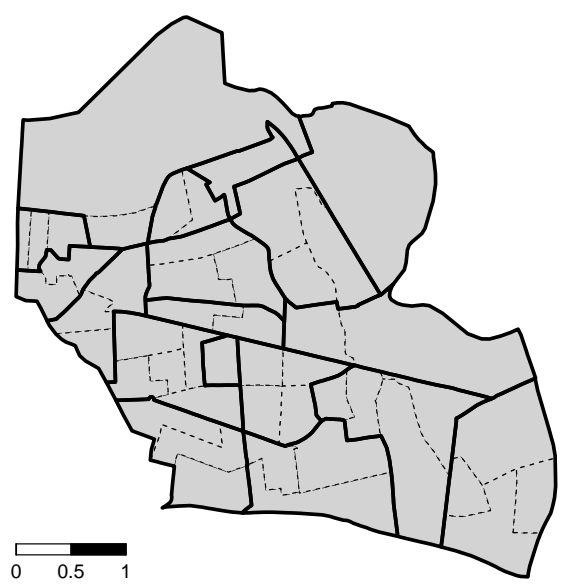

Figure 2 shows the distribution of the standardized Moran statistics for some of these variables. We can note that statistics at the neighbourhood level are much less spread out than the ones computed at the municipality level, or at urban unit level. Individuals tend to sort themselves between block-groups within urban units, between block-groups within municipalities, rather than between block-groups within neighbourhoods. In particular, the distribution of people born in different countries, regions or departments tend to be quite segregated if we 
consider the urban unit or the municipality level, which support the idea that newcomers to a city may choose the neighbourhood where they want to live, but that the exact block-group choice is subject to more randomness. Within neighbourhood, the residual variation of variables like employment-population ratio and employment rates between block-groups does not show strong spatial-autocorrelation pattern (resp. second and third rows of Figure 2).

Table 8 in appendix shows more precise statistics about the distribution of the Moran statistics. Within neighbourhood ("Grand quartier"), we would reject the null hypothesis of absence of spatial autocorrelation between 4 to $11 \%$ of the cases at a $5 \%$ level. This table also shows that the distribution of Moran statistics are more symmetrical when we consider the neighbourhood level compared to the municipality or the urban area level. Altogether, these elements suggest that spatial-autocorrelation is quite limited within neighbourhood, which supports our identification strategy.

\subsubsection{Sample Selection and External Validity}

The analysis is conducted on the sub-sample of youths living in mainland France that met the identification requirements. First, as rural and small urban municipalities are not delineated into census block-group (IRIS) by INSEE, our estimation strategies can not be implemented there. We can only use municipalities with more than 10,000 and most of the municipalities with more than 5,000 inhabitants. ${ }^{14}$ Observations from the two combined Generation surveys are located in 12,021 distinct block-groups of the 16,167 existing ones ${ }^{15}$. Second, our estimation strategy requires to have at least two respondents with different outcomes and living in different census block-groups (IRIS) within each neighbourhood ("Grand quartier"). In total, our estimations are conducted on 9,692 different block-groups.

It is worth noting that this subsample of block-groups shares almost the same characteristics as the whole set of block-groups. Table 1 shows that compared to the 16,167 existing blockgroups, block-groups in our sample are slightly smaller (the median block-groups is $0.03 \mathrm{~km}^{2}$ larger), more populated (15 more individuals aged 15-24 and 37 more individuals aged 25-64), and their density is slightly higher (24 more individual aged 15-24 and 90 more aged 25-64 per $k m^{2}$ ). Differences between the median employment rates are limited to one quarter percentage point. Women tend to live in slightly denser areas than men, but nevertheless the median levels of employment in their respective block-groups is equivalent.

\footnotetext{
${ }^{14}$ The target size of the block-groups (IRIS) is 2,000 inhabitants

${ }^{15}$ We used the 1999 delineation of the IRIS throughout this paper.
} 
Table 1: Descriptive statistics of the block-groups (IRIS)

Type of Municipality

\begin{tabular}{|c|c|c|c|c|c|c|c|c|}
\hline \multirow{3}{*}{ Median values } & \multicolumn{4}{|c|}{ All Municipalities } & \multicolumn{2}{|c|}{$\geq 5,000$ inhab. } & \multicolumn{2}{|c|}{$\geq 30,000$} \\
\hline & \multirow[b]{2}{*}{ All } & \multicolumn{3}{|c|}{ Sample } & \multicolumn{2}{|r|}{ Sample } & \multicolumn{2}{|r|}{ Sample } \\
\hline & & General & Men & Women & All & General & All & General \\
\hline Area $(\mathrm{km} 2)$ & 0.61 & 0.58 & 0.59 & 0.61 & 0.6 & 0.57 & 0.33 & 0.31 \\
\hline \multicolumn{9}{|c|}{ Population (inhab.) } \\
\hline $15-24$ & 296 & 311 & 319 & 318 & 296 & 311 & 307 & 324 \\
\hline $25-64$ & 1190 & 1227 & 1246 & 1248 & 1191 & 1227 & 1195 & 1235 \\
\hline \multicolumn{9}{|c|}{ Density (inhab./km2) } \\
\hline $15-24$ & 525 & 549 & 558 & 537 & 536 & 559 & 1068 & 1116 \\
\hline $25-64$ & 2050 & 2141 & 2158 & 2075 & 2087 & 2166 & 3788 & 3957 \\
\hline \multicolumn{9}{|c|}{ Employment-Population Ratio } \\
\hline $15-24$ & 20.45 & 20.36 & 20.19 & 20.18 & 20.47 & 20.38 & 19.82 & 19.8 \\
\hline $25-64$ & 69.91 & 69.58 & 69.41 & 69.44 & 69.93 & 69.58 & 69.69 & 69.36 \\
\hline \multicolumn{9}{|c|}{ Employment Ratio } \\
\hline $15-24$ & 19.6 & 19.82 & 19.9 & 19.92 & 19.6 & 19.84 & 20.08 & 20.3 \\
\hline $25-64$ & 80.4 & 80.18 & 80.1 & 80.08 & 80.4 & 80.16 & 79.92 & 79.7 \\
\hline
\end{tabular}

\begin{tabular}{lllllllll}
\hline Observations & 16,167 & 9,692 & 5,515 & 5,845 & 15,853 & 9,612 & 8,244 & 4,885
\end{tabular}

Notes: median values computed from the 1999 Census. "All" label indicates that statistics are obtained from all block-groups (IRIS) in urban municipalities. "General" corresponds to the block-groups where were located individuals from the Generation surveys (1998 and 2004) included in the estimation sample. "Men" and "Women samples" correspond to the subsamples of block-groups where were located the individuals used to obtain the corresponding estimates displayed in the next tables. 
Figure 2: Distribution of Moran indices for different block-group characteristics

(a) Born on in the same Department

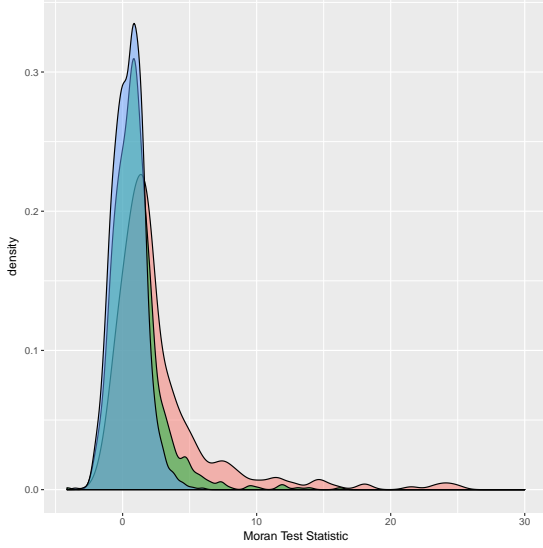

(d) Emp. Pop. Ratio 15-24

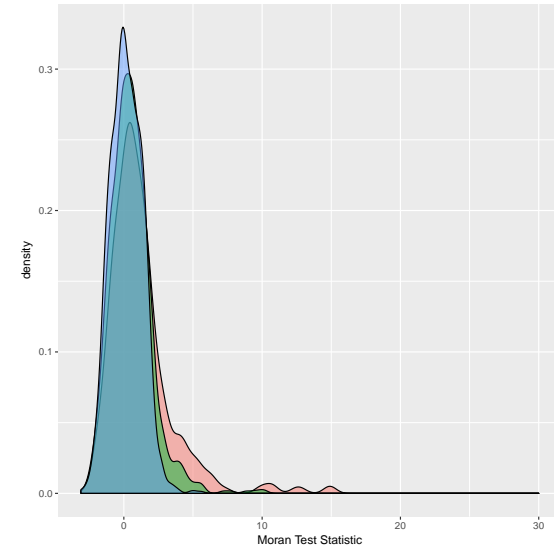

(g) Emp. rate 15-24

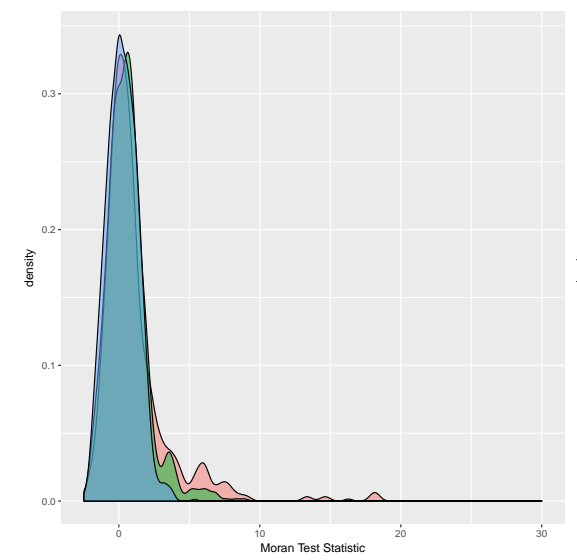

Level (b) Born on in the same Region

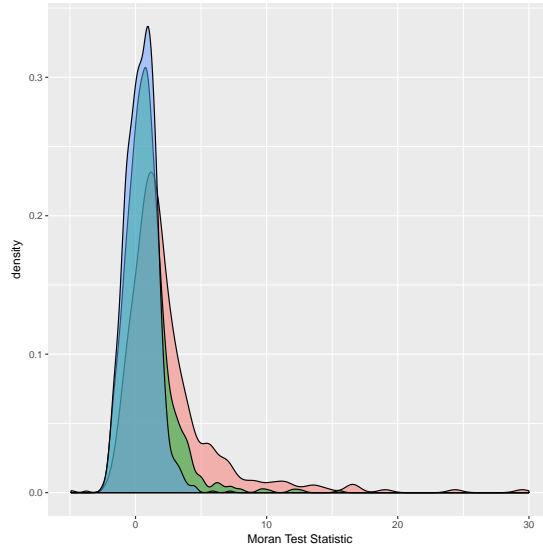

(e) Emp. Pop. Ratio 25-64

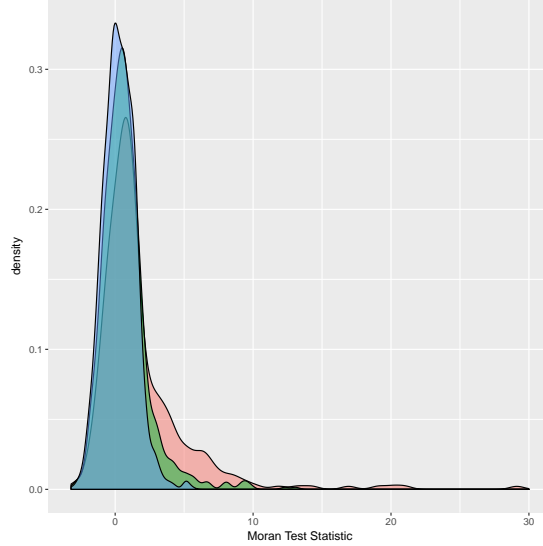

(h) Emp. rate 25-64

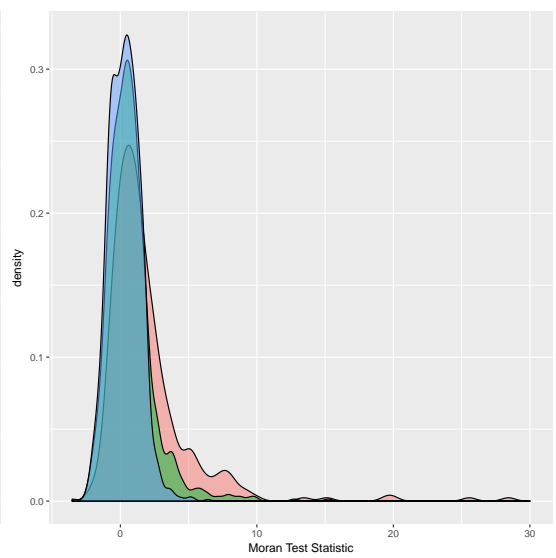

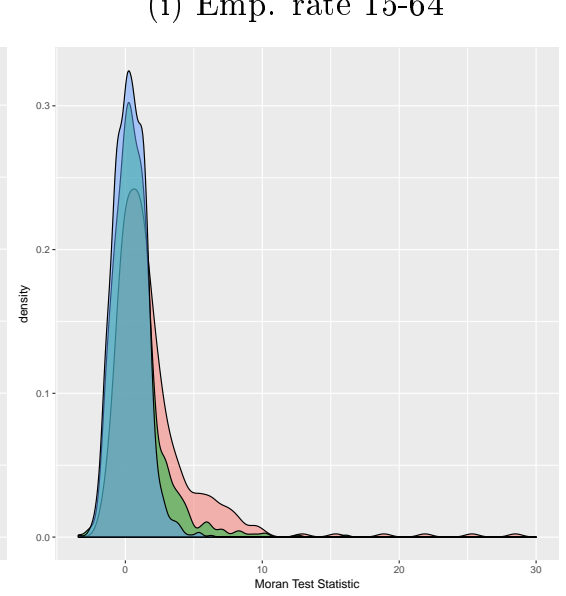

(c) Born on in France

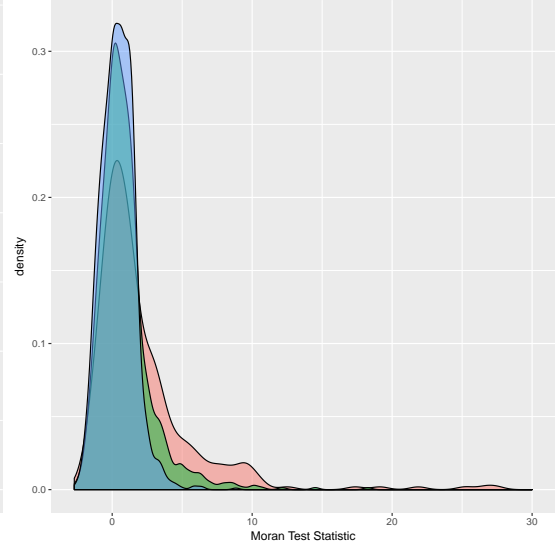

(f) Emp. Pop. Ratio 15-64

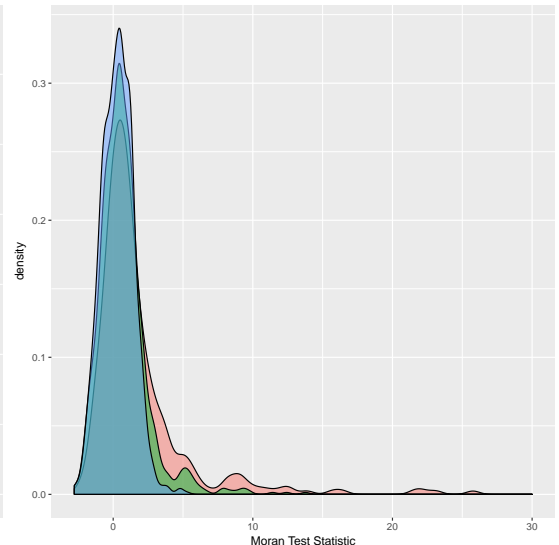

(i) Emp. rate 15-64

Almost all the block-groups (98\%) covered by our study sample are located in municipalities having at least 5,000 inhabitants in 1999. When restricting to these municipalities, differences between block-groups are even smaller. This trend is more obvious when restrict- 
ing to municipalities over 30,000 inhabitants showing that the initial differences where due to small municipalities that are less often in our sample. Overall, our sample provides a good representation of the municipalities with populations over 5,000 regarding age composition, population, density, and employment. Thus, the external validity of the analysis does not seem to be compromised, allowing us to generalize the results in municipalities of mainland France of over 5,000 inhabitants ${ }^{16}$.

\subsection{Individual Descriptive Statistics}

Individual characteristics are presented in Table 2. The table shows the impact of the sample selection on the sample characteristics: among the surveyed individuals living in urban municipalities (All), we compare individuals that are excluded from the analysis (Exc) to those which are included (Incl). Selection plays a role in terms of employment since our identification strategy requires variation of employment status for individuals living in the same neighbourhood. Thus it also plays a role in the distributions of the variables that strongly correlate with employment situation, like education. However, the selection remains fairly limited. First more than $84 \%$ of the Generation survey sample (rural municipalities excluded) is included in our final sample (Incl). And if the sample difference between individual employment rate is large and above 3 percentage points (80.98 vs $77.68 \%$ ), the difference in terms of local indices is much smaller and below a quarter-point (74.76 vs $74.52 \%$ for the employment rate of young and 25.10 and $24.94 \%$ for the employment rate ratio). In total, our analysis is made with 26,751 observations, which reduce to 10,507 and 10,874 when we separately analyse men and womenseparately ${ }^{17}$.

The age difference with respect to the average age of people getting the same degree ${ }^{18}$, and whether the individual repeated a year in primary school are also used as proxies for schooling ability. It is particularly interesting to notice that more than three-quarter of the youth, and even two-third of the young men did not go to college ("college", "higher graduate") which reinforces the role of ties developed in their residential neighbourhood. Note that education may be endogenous, since the decision of leaving school may be driven by favourable labour market situations. However, such an effect would arise at a larger level than the block-group

\footnotetext{
${ }^{16}$ Almost 1,900 municipalities in 1999. Three quarters of them are covered by our study sample.

${ }^{17}$ As the estimation strategy then requires to have at least two respondents of the same gender with different outcomes and living in different census block-groups (IRIS) within each neighbourhood

${ }^{18}$ This variable was obtained by simply subtracting the average age of individuals within the same degree from the age of the individual when he left school
} 
level, and controlling for the neighbourhood fixed effect prevents from this potential issue.

Past residential mobility during education is also accounted for. We know if individuals were in the same municipality when they began high school, and when they left school. Nearly 9 out of 10 individual stayed in the same municipality from 6th grade to the end of their education period, meaning that they have been living in the same area for 8.7 years ${ }^{19}$. We also have information about their living arrangements: the vast majority of individuals still live with their parents when they leave school $(70 \%)$. These two elements suggest the strength of the link between residence location and individuals behaviours.

We also include variables to control for the role of parents in the labour market transition: we take into account their occupation distinguishing blue/white-collar parents ${ }^{20}$ (52\%) from intermediate occupations, executive, or craftsman. Parents labour market status is also of primary importance to describe the intensity of the potential links with the labour market: for most individuals, both parents are working (57.85\%), 28.48\% of them have one working parent, $12.75 \%$ have at least one parent that worked in the past and less than one percent have parents who never worked. We also take into account the foreign origin of parents: $86 \%$ of individuals have two parents born in France, $8 \%$ have at least one immigrant parent born in Africa, and the remaining $10 \%$ have at least one parent born in another foreign country. As we use both Génération surveys from 1998 and 2004, a dummy variable for the 2004 cohort respondents (about $38 \%$ of the sample) is added.

Table 2 also highlights major gender differences. Women tend to be more educated than men: their proportion of high-school dropouts is 10 points lower while the proportion of them attending college is 8 points higher. This may partly explain why women have a greater tendency to move between 6th grade and the end of their education (88.37 vs $85.24 \%$ ) and why one-third of them already left the parental home before the end of their education. In any case, these gender variations lead to a potentially different link with the area they are living in. Other characteristics of men and women parents are quite similar.

Table 3 describes the different employment indices we use in our studies. As stated before, we distinguish employment-population ratios from employment rates, and we use different rates computed over different sub-populations: young individuals (15 to 24 years old) and older ones (25 to 64 years old), and male and female ratios. From these descriptives statistics, we can see

\footnotetext{
${ }^{19}$ Average difference between age at the end of the education period and age in 6th grade.

${ }^{20}$ As most white-collar women have a blue-collar male partner, it is difficult to make a clear distinction between these 2 groups.
} 
Table 2: Descriptive Statistics: Individual and Family Characteristics

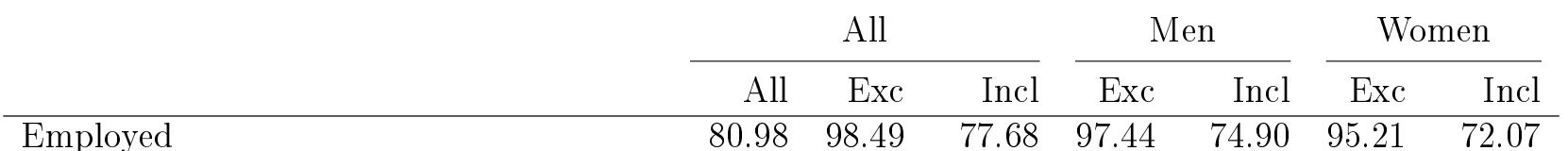

\section{Individual Characteristics}

Education

High-school dropouts

Short prof. tracks

General high-school

Community college

College

Higher graduate

$\begin{array}{rrrrrrr}16.57 & 13.87 & 17.08 & 18.80 & 22.55 & 9.57 & 12.72 \\ 16 & 15.26 & 16.13 & 19.76 & 19.82 & 10.76 & 12.64 \\ 23.01 & 21.51 & 23.30 & 21.47 & 21.88 & 22.40 & 25.18 \\ 17.08 & 20.46 & 16.44 & 14.93 & 12.98 & 24.16 & 19.05 \\ 13.39 & 13.16 & 13.44 & 10.26 & 9.62 & 16.85 & 17.13 \\ 13.95 & 15.74 & 13.61 & 14.77 & 13.14 & 16.27 & 13.28\end{array}$

Age diff. wrt Average age in the diploma

Repeating a year in primary school

End of education in 2004

$\begin{array}{rrrrrrr}0 & 0.01 & 0.00 & -0.04 & -0.04 & 0.02 & 0.05 \\ 19.8 & 17.86 & 20.16 & 22.76 & 23.80 & 14.23 & 16.83 \\ 37.68 & 37.81 & 37.65 & 36.58 & 37.55 & 38.02 & 38.22\end{array}$

Living Arrangement when leaving school

Parental home

Living in couple

Single

$\begin{array}{lllllll}69.41 & 66.92 & 69.88 & 72.98 & 76.45 & 61.15 & 64.39 \\ 16.28 & 17.82 & 15.99 & 12.29 & 10.50 & 23.42 & 20.80 \\ 14.31 & 15.26 & 14.13 & 14.74 & 13.05 & 15.43 & 14.81\end{array}$

Residential immobility during education

Same municipality since 6th grade

Immobility duration (years)

$\begin{array}{rrrrrrr}86.55 & 85.97 & 86.66 & 88.12 & 88.37 & 83.67 & 85.24 \\ 8.75 & 8.86 & 8.73 & 8.75 & 8.56 & 8.97 & 8.85\end{array}$

\section{Parents Characteristics}

Occupation

Blue/white-collar

Intermediate

$52.41 \quad 50.62$

52.97

49.59

52.68

$\begin{array}{ll}10.21 & 10.22\end{array}$

$10.21 \quad 10.69$

9.95

$10.19 \quad 10.23$

Executive

$25.01 \quad 26.85$

$24.66 \quad 25.98$

$\begin{array}{lll}23.94 & 27.34 & 24.52\end{array}$

Craftsman

$12.83 \quad 13.46$

$12.72 \quad 12.71$

$13.14 \quad 12.87$

12.58

Employment Status

Two working parents

One working parent

$57.85 \quad 61.32$

\begin{tabular}{ll}
$57.20 \quad 59.94$ \\
\hline
\end{tabular}

55.73

$\begin{array}{ll}61.52 & 57.21\end{array}$

$28.48 \quad 25.66$

$29.02 \quad 27.22$

$29.49 \quad 26.48$

29.04

One former worker

$12.75 \quad 12.36$

$12.83 \quad 12.18$

$\begin{array}{lll}13.81 & 11.26 & 12.68\end{array}$

Never work/unknown parents

$0.91 \quad 0.65$

$0.96 \quad 0.66$

$\begin{array}{lll}0.96 & 0.73 & 1.07\end{array}$

Migration Status

Native French parents

One African immigrant

$\begin{array}{lllllll}82.09 & 85.16 & 81.51 & 84.11 & 80.16 & 84.61 & 81.80\end{array}$

One immigrant (other)

$8.14 \quad 8.16$

$8.14 \quad 8.68$

$8.40 \quad 7.60$

7.85

Observations

\begin{tabular}{rrrrrrr}
9.77 & 6.69 & 10.35 & 7.21 & 11.44 & 7.79 & 10.35 \\
\hline
\end{tabular}

Notes: computed from the Generation surveys (1998 and 2004). Average characteristics are taken for the whole population (All panel), the population of Men only, and the population of Women. For each population, the "Exc" column corresponds to the subsample of individuals excluded from the estimation sample, whereas the "Incl" column corresponds to the subsample of individuals included in the estimation sample. 
Table 3: Descriptive Statistics: Local employment rates characteristics

\begin{tabular}{|c|c|c|c|c|c|c|}
\hline \multicolumn{3}{|c|}{ All } & \multicolumn{2}{|c|}{ Men } & \multicolumn{2}{|c|}{ Women } \\
\hline All & Exc & Incl & Exc & Incl & Exc & Incl \\
\hline
\end{tabular}

Block-group Employment Rate

All 15-24

All 25-64

$\begin{array}{llll}74.76 & 76.04 & 74.52 & 75.46\end{array}$

$\begin{array}{llll}87.31 & 88.08 & 87.17 & 88.03\end{array}$

$\begin{array}{lll}74.17 & 75.92 & 74.46\end{array}$

Male 15-24

Male 25-64

$\begin{array}{llll}72.7 & 74.23 & 72.41 & 73.52\end{array}$

$\begin{array}{llll}88.76 & 89.50 & 88.62 & 89.50\end{array}$

$\begin{array}{lll}71.92 & 73.94 & 72.48\end{array}$

Female 15-24

$\begin{array}{llll}72.94 & 74.09 & 72.72 & 73.36\end{array}$

$\begin{array}{lll}88.44 & 89.25 & 88.47\end{array}$

Female 25-64

$\begin{array}{llll}85.52 & 86.34 & 85.36 & 86.19\end{array}$

$85.15 \quad 86.23$

85.21

Block-group Employment-Population Ratio

All 15-24

All 25-64

$\begin{array}{llll}25.1 & 25.98 & 24.94 & 25.37\end{array}$

$\begin{array}{llll}68.63 & 69.58 & 68.45 & 69.29\end{array}$

$\begin{array}{lll}24.83 & 25.60 & 25.01\end{array}$

Male 15-24

$\begin{array}{lllllll}27.23 & 28.17 & 27.06 & 27.64 & 27.03 & 27.69 & 27.02\end{array}$

Male 25-64

$\begin{array}{llll}75.27 & 76.12 & 75.11 & 76.00\end{array}$

$\begin{array}{llll}22.89 & 23.71 & 22.73 & 23.02\end{array}$

$\begin{array}{lll}74.88 & 75.91 & 74.99\end{array}$

Female 15-24

$\begin{array}{llll}62.35 & 63.36 & 62.16 & 62.91\end{array}$

$\begin{array}{lll}22.53 & 23.44 & 22.92\end{array}$

Female 25-64

$62.35-63.36-62.16-62.91$

$61.87 \quad 63.44$

62.05

Distinct Areas in the Sample

Unique Urban Units

Unique Neighbourhoods

$\begin{array}{lllllll}759 & 337 & 599 & 486 & 418 & 445 & 468\end{array}$

Unique Block-groups

$\begin{array}{lllllll}3,745 & 1,205 & 2,540 & 1,921 & 1,584 & 1,732 & 1714\end{array}$

Observations

\begin{tabular}{rrrrrrr}
12,021 & 2,329 & 9,692 & 3,552 & 5,515 & 3,107 & 5,845 \\
\hline 31,790 & 5,039 & 26,751 & 5,632 & 10,507 & 4,777 & 10,874
\end{tabular}

Notes: Source: Generation surveys (1998 and 2004) and Census. 
that young people have much lower employment rates and employment population ratios than older ones. Moreover, although young male and female have quite similar employment rates, older women have lower employment rates. The difference between genders is much stronger when we consider employment population ratios, since this index accounts for labour market participation and education enrolment (for the younger group), and women tend to be more educated and participate less to the labour market.

The positive correlation between the local employment rates where individuals were living when they finished school, and his own employment situation three years after can be observed in Figure 3. For most indices, the probability to have a job increases with the proportion of employed persons in the block-group. This results is true for both men and women. One exception is the 15-24 employment-population ratio, which appears to be negatively correlated to the individual employment situation over the whole population. This correlation may be driven by the large share of 15-24 who are in education that contributes to this particular ratio.

Figure 3: Correlation between local employment ratios in the area at the end of education, and the youth employment three years later

(a) All

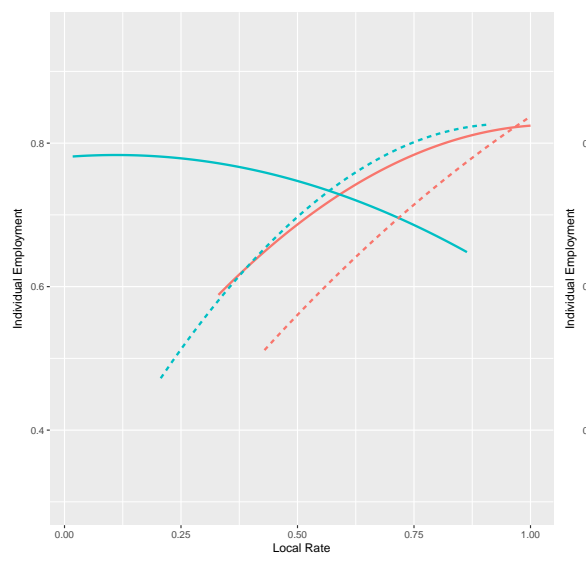

Age group - 15-24 - - 25-64 (b) Men

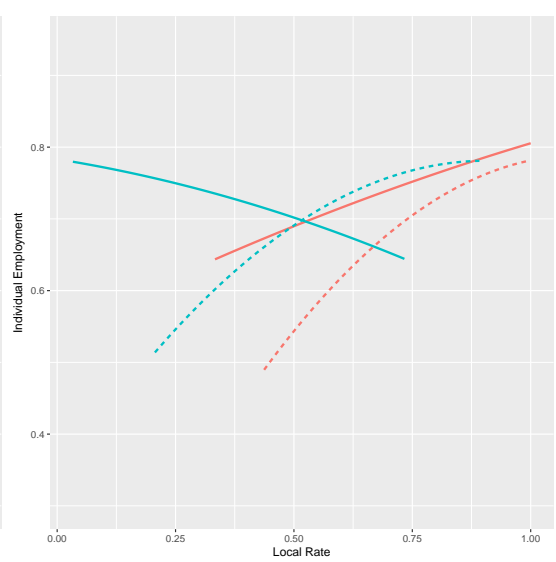

Rate - Employment — Employment-Population (c) Women

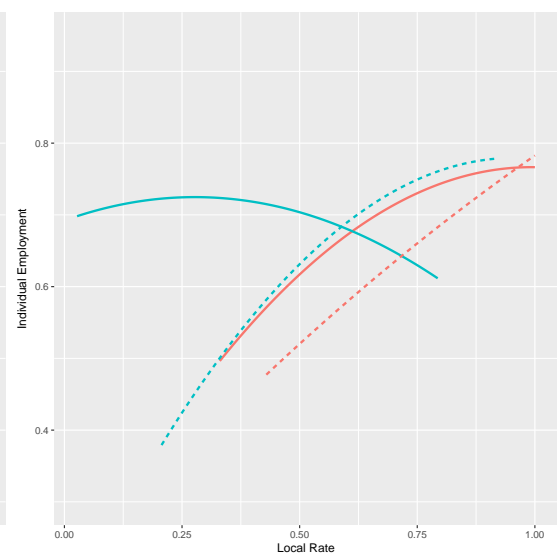

Note: Source: Generation surveys (1998 and 2004) and Census. Representations were obtained using quadratic fit. They are drawn for the actual range of each variable.

Figure 4 details this description by gender-specific rates and ratios. We can see a clear difference for men between the correlations with males rates (Figure 4a) that are higher than the one observed with female rates (Figure 4b). Considering women, the difference between gender ratios is not clear (see Figures $4 \mathrm{c}$ and $4 \mathrm{~d}$ ). 
Figure 4: Correlation between gender specific local employment ratios in the area at the end of education, and the youth employment by gender three years later

(a) Men, Male rates

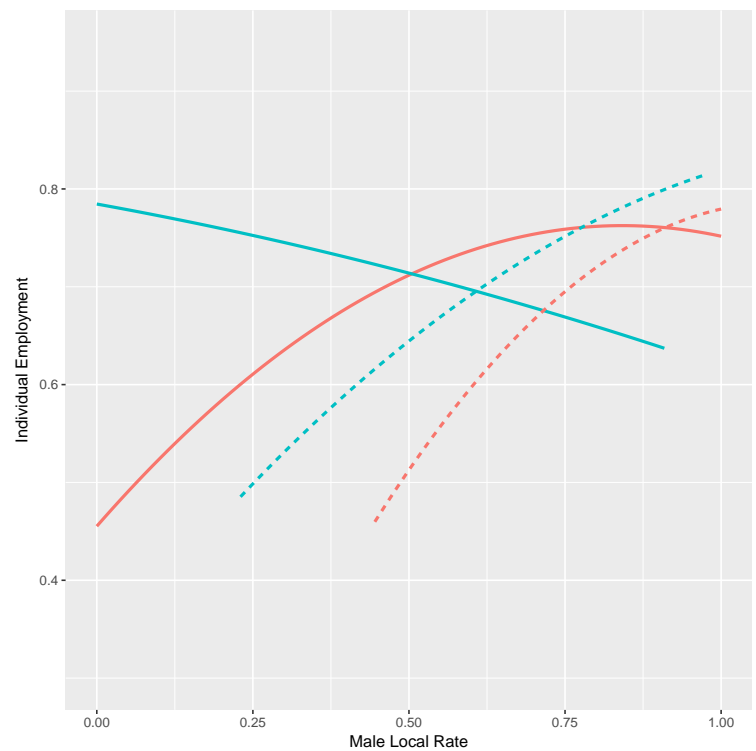

(c) Women, Male rates

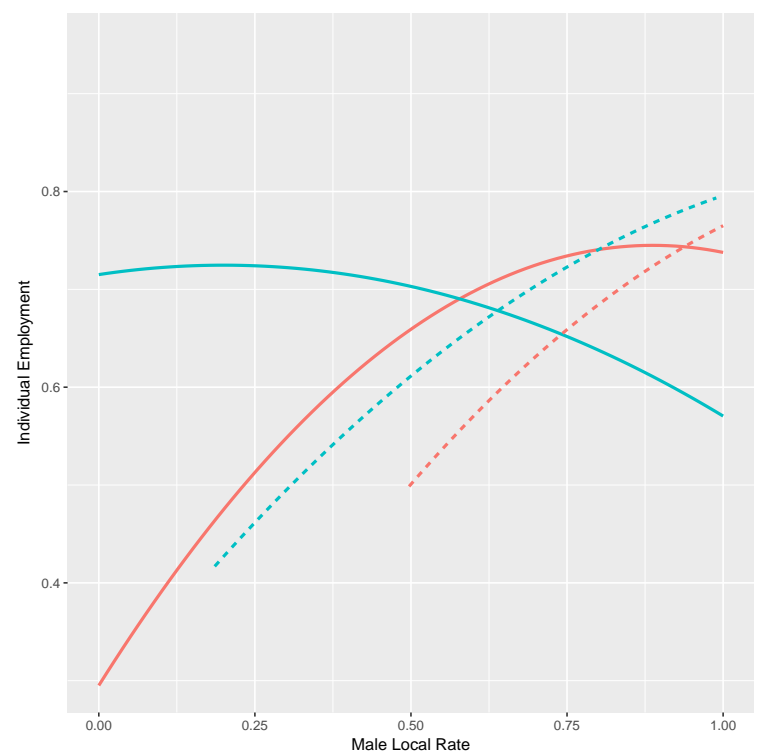

(b) Men, Female rates

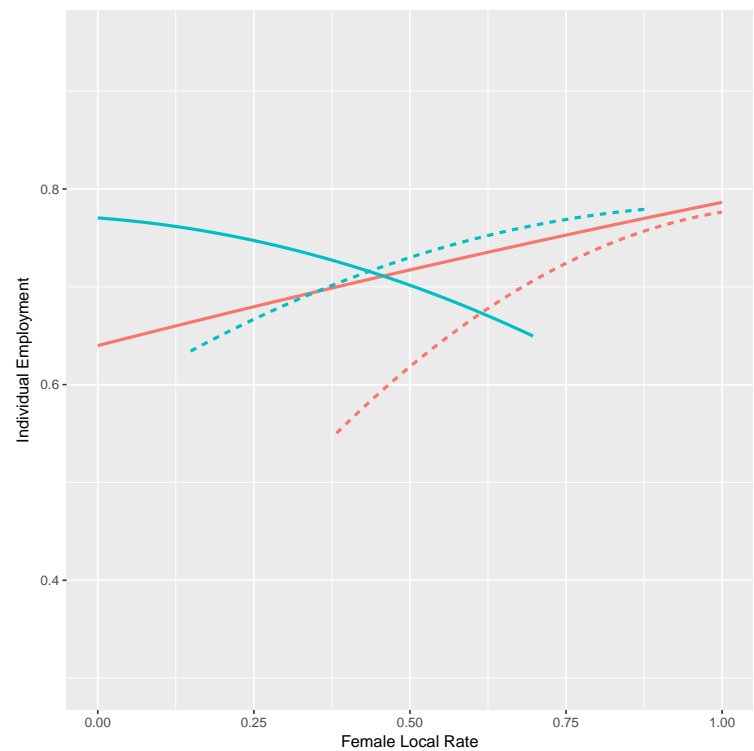

(d) Women, Female rates

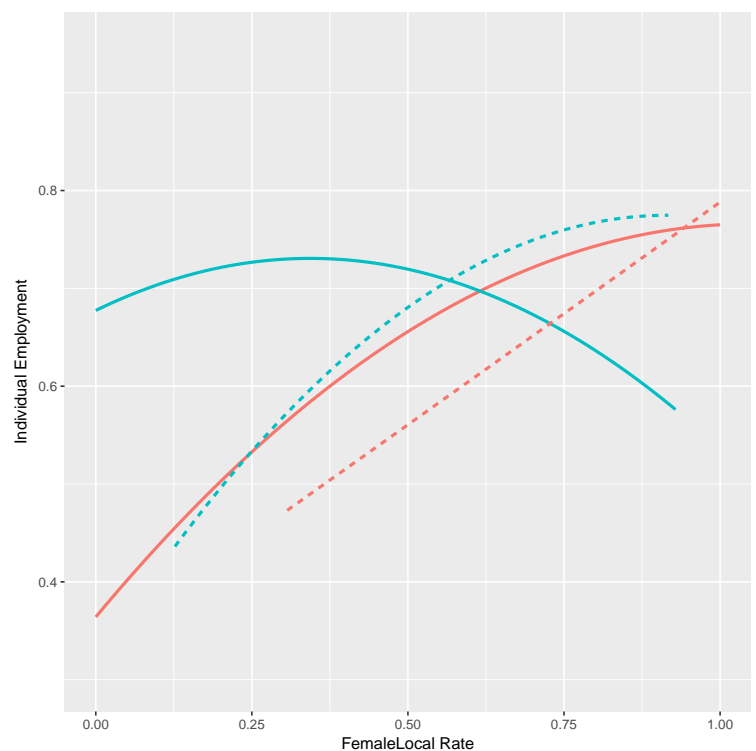

Age group - 15-24 = - 25-64 Rate - Employment - Employment-Population

Note: Source: Generation surveys (1998 and 2004) and Census. Representations were obtained using quadratic fit. They are drawn for the actual range of each variable. 


\section{$5 \quad$ Results}

\subsection{Impacts of Local Employment Rates on School-to-Work Transi- tion}

Table 4 presents the estimates of the marginal effect of the local employment rates measured at the block-group level (IRIS) on later individual employment status. ${ }^{21}$ Each column of the table corresponds to a particular local rate (Employment-Population Ratio, or Employment Rate), computed for a particular age group (15-24 or 25-64). For each rate, estimates were obtained by a standard logit model (Exo.) or using a fixed effect estimator in order to control for further sorting behaviour (FE).

Table 4: Estimates of the Marginal effects

\begin{tabular}{|c|c|c|c|c|c|c|c|c|}
\hline & \multicolumn{4}{|c|}{ Employment-Population Ratio } & \multicolumn{4}{|c|}{ Employment Rate } \\
\hline & \multicolumn{2}{|c|}{$15-24$} & \multicolumn{2}{|c|}{$25-64$} & \multicolumn{2}{|c|}{$15-24$} & \multicolumn{2}{|c|}{$25-64$} \\
\hline & Exo. & FE & Exo. & FE & Exo. & FE & Exo. & FE \\
\hline \multicolumn{9}{|l|}{ Baseline Specification } \\
\hline \multirow[t]{2}{*}{ All } & $0.16^{* * *}$ & 0.09 & $0.13^{* * *}$ & $0.14^{* * *}$ & $0.13^{* * *}$ & $0.12^{* * *}$ & $0.22^{* * *}$ & $0.14^{* * *}$ \\
\hline & $(0.03)$ & $(0.06)$ & $(0.03)$ & $(0.04)$ & $(0.02)$ & $(0.03)$ & $(0.04)$ & $(0.03)$ \\
\hline $\mathrm{N}$ & 26751 & 26751 & 26751 & 26751 & 26751 & 26751 & 26751 & 26751 \\
\hline \multirow{2}{*}{ Municipality $>5,000$} & $0.16^{* * *}$ & $0.09^{*}$ & $0.14^{* * *}$ & $0.14^{* * *}$ & $0.13^{* * *}$ & $0.12^{* * *}$ & $0.22^{* * *}$ & $0.14^{* * *}$ \\
\hline & $(0.03)$ & $(0.06)$ & (0.03) & $(0.03)$ & $(0.02)$ & $(0.03)$ & $(0.04)$ & $(0.03)$ \\
\hline $\mathrm{N}$ & 26459 & 26459 & 26459 & 26459 & 26459 & 26459 & 26459 & 26459 \\
\hline \multirow{2}{*}{ Municipality $>30,000$} & $0.13^{* * *}$ & 0.07 & $0.13^{* * *}$ & $0.16^{* * *}$ & $0.12^{* * *}$ & $0.10^{* *}$ & $0.19^{* * *}$ & $0.15^{* * *}$ \\
\hline & $(0.05)$ & $(0.09)$ & $(0.04)$ & $(0.05)$ & $(0.03)$ & $(0.05)$ & $(0.05)$ & $(0.05)$ \\
\hline $\mathrm{N}$ & 12590 & 12590 & 12590 & 12590 & 12590 & 12590 & 12590 & 12590 \\
\hline \multicolumn{9}{|c|}{ Controlling for Local characteristics } \\
\hline \multirow[t]{3}{*}{ All } & $0.19^{* * *}$ & 0.10 & $0.25^{* * *}$ & $0.17^{* * *}$ & $0.24^{* * *}$ & $0.14^{* * *}$ & $0.44^{* * *}$ & $0.16^{* * *}$ \\
\hline & $(0.03)$ & $(0.06)$ & $(0.04)$ & $(0.04)$ & $(0.03)$ & $(0.03)$ & $(0.05)$ & $(0.02)$ \\
\hline & 26751 & 26751 & 26751 & 26751 & 26751 & 26751 & 26751 & 26751 \\
\hline
\end{tabular}

Note: Source: Generation surveys (1998 and 2004). All estimations include controls for education, age, past mobility, living arrangement, and parental characteristics. Standard errors are in parenthesis. ${ }^{*} p<0.1,{ }^{* *}$ $p<0.05,{ }^{* * *} p<0.01$ Column names indicate the rate used as explanatory variable. Exogenous model (Exo.) was estimated using logit models, and Fixed effect estimates(FE) were obtained using a conditional logit models. In the case of $\mathrm{FE}$ models, marginal effects were obtained by fixing the unobserved heterogeneity term to 0 .

\footnotetext{
${ }^{21}$ The average marginal effects are calculated for fixed effects equal to 0 . Indeed the method of estimation differentiates out the area fixed effects, and it is not possible to estimate them. Tables with other parameter estimates are reported in Appendix C.
} 
The first panel of the Table 4 details the main specification. It shows a positive and strongly significant relationship between local employment rate when leaving school, and individual employment three years later. The positive correlations observed Figure 3 are confirmed, the negative one is ruled out. Indeed, a one percentage point increase in the employment-population ratio of 15 to 24 years is associated with a .16 point increase in youth employment probability, despite its rather negative link with the employment situation of the youth entering the job market we initially observed Figure $3 .^{22}$ The value of this effect is of similar magnitude (.13) when using the Employment Population Ratio (EPR) of older neighbours, or the employment rate (ER) of 15-24 years old. It reaches .22 using the ER of the 25-64 age group. The use of a Fixed effect strategy (FE) tend to lower the marginal effects. Although this difference is not systematic, and is not statistically significant, it supports the existence of sorting between neighbourhood. Almost all marginal effects remain significant at a 5\% level, ranging from .09 to 14 .

As a robustness check, the second part of Table 4 shows estimates controlling for additional block-group characteristics taken from the census, and describes the social composition of each each block-group ${ }^{23}$. With the inclusion of these covariates, estimates remain strong. These estimates tend to be even larger than the ones obtained without the inclusion of additional covariates. Table 10 shows the coefficients associated to these variables in the regression. Focusing on the fixed-effect estimation, and comparing the estimates obtained with and without additional contextual covariates, we find no significant differences between the parameters of interest.

Table 4 also shows some robustness tests estimating the model on subsamples of municipality. The effect we find on the subsample of municipalities larger than 5,000 and 30,000 inhabitants are qualitatively similar to the ones obtained on the whole population living in urban municipalities. Points estimates are even slightly larger when we exclude municipality smaller than 5,000 inhabitants. When excluding municipality smaller than 30,000 inhabitants, points estimates are similar, but the sample size is drastically reduced.

It is interesting to note the differences we find between men and women. Once we control for sorting, EPR effects are pretty similar for men and women, ranging from .13 to .18 in the baseline specification (Tab.5, first panel). The effect of ER is of same magnitude for

\footnotetext{
${ }^{22}$ Such a discrepancy may be explained by the different functional forms that are used. Indeed, curves rely on a quadratic form whereas a logistic specification is used for regressions.

${ }^{23}$ See Appendix B
} 
men (.15) but lower for women, the 0.09 marginal effect of the 25-64 ER being even not statistically significant (.1 level) in the baseline specification. ${ }^{24}$ The fact that women seems to be more affected by employment-population ratio could suggest that women of their age living immediately around play an important role in their labour force participation decision. While ER may primarily reflect potential effect of word-of-mouth labour market networks, EPR could reflect the influence of people having a job as role-model, and the effect of norms toward women.

Using gender-specific employment indices is also particularly enlightening. In the second and third panels of Table 5, we report the results of the baseline specification using such indices. Once FE are included, youth almost exclusively react to the employment ratio specific to their gender group. It is worth noticing that men are equally affected by the share employed men among the men in the labour force (ER) and by the men employment-population ratio (EPR). For women, this equivalence between the two rates only prevails when considering the group of young women (15-24). These results suggest that the employment of women is more affected by the effect of their local peers in terms of sex and age. However, the meanings of the variation of the effect by age groups remains more elusive. ER of older women (25-64) are lower (.09) and not statistically significant (.1 level) once FE are used. On the contrary, the effect of the 25-64 EPR could suggest the role of older women in providing job opportunities for younger ones entering the job market. Thus, regarding employment, gender group seems to be a key characteristic in the definition of the effective peers.

\subsection{Education and Social Effect}

The results we previously described were obtained in a framework where effects were supposed to be homogeneous for the whole population, or separately for men and women. Here we ask whether the sensitivity to the local context is heterogeneous with respect to other individual characteristics. Tables 6 and 7 show the average marginal effects obtained from models that interact the employment rate of interest with education, national origin and living arrangement for men and women respectively.

The first panel of Table 6 shows the heterogeneity of the neighbourhood effect according to the level of education of men. The contextual effect (endogenous effect in Manski's categories) on the probability of getting a job seems limited to high-school dropouts. The marginal effect

\footnotetext{
${ }^{24}$ Such a different pattern between men and women is also observed at an even larger scale when distinguishing by municipality size (results not included).
} 
Table 5: Estimates: gender specific explanatory variable

Employment-Population Ratio

15-24 25-64

Employment Rate

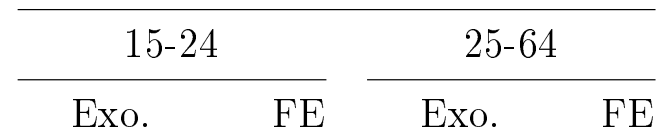

Baseline Specification

\begin{tabular}{lrrrrrrrr} 
Men & $0.18^{* * *}$ & $0.18^{*}$ & 0.04 & $0.13^{*}$ & $0.08^{* *}$ & $0.15^{* * *}$ & $0.15^{* *}$ & $0.15^{* *}$ \\
$\mathrm{~N}$ & $(0.06)$ & $(0.10)$ & $(0.05)$ & $(0.08)$ & $(0.04)$ & $(0.05)$ & $(0.06)$ & $(0.07)$ \\
& 10507 & 10507 & 10507 & 10507 & 10507 & 10507 & 10507 & 10507 \\
\multirow{2}{*}{ Women } & & & & & & & & \\
& & & & & & & & \\
$\mathrm{N}$ & $(0.06)$ & $(0.08)$ & $(0.05)$ & $(0.06)$ & $(0.04)$ & $(0.05)$ & $(0.06)$ & $(0.08)$ \\
$\mathrm{N}$ & 10874 & 10874 & 10874 & 10874 & 10874 & 10874 & 10874 & 10874
\end{tabular}

Gender specific explanatory variable: Male population

\begin{tabular}{lrrrrrrrr}
\hline Male ratio & $0.17^{* * *}$ & $0.15^{*}$ & $0.11^{* *}$ & $0.15^{* *}$ & $0.08^{* *}$ & $0.12^{* *}$ & $0.19^{* * *}$ & $0.15^{* *}$ \\
$\mathrm{~N}$ & $(0.05)$ & $(0.08)$ & $(0.05)$ & $(0.07)$ & $(0.03)$ & $(0.05)$ & $(0.06)$ & $(0.07)$ \\
& 10507 & 10507 & 10507 & 10507 & 10507 & 10507 & 10507 & 10507 \\
\multirow{2}{*}{ Female ratio } & $0.10^{*}$ & 0.11 & -0.01 & 0.09 & 0.04 & $0.09^{*}$ & 0.07 & 0.10 \\
& $(0.05)$ & $(0.09)$ & $(0.04)$ & $(0.08)$ & $(0.03)$ & $(0.05)$ & $(0.05)$ & $(0.08)$ \\
$\mathrm{N}$ & 10507 & 10507 & 10507 & 10507 & 10507 & 10507 & 10507 & 10507
\end{tabular}

Gender specific explanatory variable: Female population

\begin{tabular}{lrrrrrrrr}
\hline Male ratio & $0.13^{* * *}$ & 0.05 & $0.10^{* *}$ & 0.08 & $0.07^{*}$ & 0.05 & 0.10 & 0.08 \\
$\mathrm{~N}$ & $(0.05)$ & $(0.07)$ & $(0.05)$ & $(0.07)$ & $(0.03)$ & $(0.05)$ & $(0.06)$ & $(0.09)$ \\
& 10874 & 10874 & 10874 & 10874 & 10874 & 10874 & 10874 & 10874 \\
Female ratio & $0.23^{* * *}$ & $0.19^{* * *}$ & $0.11^{* * *}$ & $0.16^{* * *}$ & $0.09^{* * *}$ & $0.11^{* * *}$ & $0.11^{* *}$ & 0.09 \\
& $(0.05)$ & $(0.07)$ & $(0.04)$ & $(0.05)$ & $(0.03)$ & $(0.04)$ & $(0.05)$ & $(0.07)$ \\
$\mathrm{N}$ & 10874 & 10874 & 10874 & 10874 & 10874 & 10874 & 10874 & 10874
\end{tabular}

Note: Source: Generation surveys (1998 and 2004). All estimations include controls for education, age, past mobility, living arrangement, and parental characteristics. Standard errors are in parenthesis. ${ }^{*} p<0.1,{ }^{* *}$ $p<0.05,{ }^{* * *} p<0.01$ Column names indicate the type of rate used as explanatory variable. In the second and third part of the table, row names complete that information by indicating the gender specific explanatory variables (Male ratio or Female ratio) used as explanatory variable. Exogenous model (Exo.) was estimated using logit models, and Fixed effect estimates(FE) were obtained using a conditional logit models. In the case of FE models, marginal effects were obtained by fixing the unobserved heterogeneity term to 0 .

is large ranging from .25 to .42 according to the chosen index.

This category of young workers generally has very low qualifications, and few direct links to the labour markets (through seasonal work or intern-ship for instance). Contrary to the individuals who go to college, they have also had fewer opportunities to develop their social 
Table 6: Marginal Effects From Models with Interactions (Men), Model with Fixed-Effects

Employment-

Population Ratio Employment Rate

15-24 25-64 $\quad$ 15-24 25-64

\begin{tabular}{lrrrr} 
Estimation by Level of Education & & & \\
Drop Out & $0.42^{* * *}$ & $0.31^{* * *}$ & $0.25^{* * *}$ & $0.32^{* * *}$ \\
& $(0.16)$ & $(0.11)$ & $(0.10)$ & $(0.06)$ \\
Short prof Tracks & 0.16 & 0.10 & 0.13 & 0.10 \\
& $(0.15)$ & $(0.11)$ & $(0.10)$ & $(0.11)$ \\
High School graduate & 0.12 & -0.09 & 0.13 & -0.03 \\
& $(0.14)$ & $(0.13)$ & $(0.10)$ & $(0.12)$ \\
Community College & -0.13 & -0.10 & -0.00 & -0.05 \\
& $(0.15)$ & $(0.12)$ & $(0.10)$ & $(0.11)$ \\
College & $0.35^{*}$ & 0.12 & 0.13 & 0.02 \\
& $(0.19)$ & $(0.15)$ & $(0.12)$ & $(0.14)$ \\
Higher & 0.04 & 0.16 & 0.09 & 0.11 \\
& $(0.14)$ & $(0.11)$ & $(0.09)$ & $(0.12)$ \\
\hline
\end{tabular}

Estimation by Parents' Migration Status

\begin{tabular}{lrrrr} 
Native French parents & $0.19^{* *}$ & $0.15^{*}$ & $0.14^{* * *}$ & $0.15^{* *}$ \\
& $(0.10)$ & $(0.08)$ & $(0.05)$ & $(0.07)$ \\
One immigrant (other) & 0.27 & -0.19 & 0.03 & -0.10 \\
& $(0.23)$ & $(0.20)$ & $(0.15)$ & $(0.23)$ \\
One African immigrant & 0.06 & 0.23 & $0.29^{* *}$ & 0.25 \\
& $(0.20)$ & $(0.16)$ & $(0.14)$ & $(0.18)$ \\
\hline
\end{tabular}

Estimation by Living Arrangement when leaving school

$\begin{array}{lrrrr}\text { Parental home } & 0.21^{*} & 0.15^{*} & 0.18^{* * *} & 0.16^{* *} \\ \text { Living in couple } & (0.11) & (0.09) & (0.05) & (0.08) \\ & 0.09 & 0.14 & 0.02 & 0.17 \\ \text { Single } & (0.15) & (0.14) & (0.10) & (0.16) \\ & 0.12 & 0.01 & 0.01 & 0.02 \\ \text { N } & (0.17) & (0.17) & (0.12) & (0.19) \\ & 10507 & 10507 & 10507 & 10507\end{array}$

Note: Source: Generation 98 and Generation 04. All estimations include controls for education, age, past mobility, living arrangement, and parental characteristics. Standard errors are in parenthesis. ${ }^{*} p<0.1,{ }^{* *}$ $p<0.05,{ }^{* * *} p<0.01$ Column names indicate the rate use as explanatory variable. Exogenous model (Exo.) was estimated using logit models, and Fixed effect estimates(FE) were obtained using a conditional logit models. In the case of FE models, marginal effects were obtained by fixing the unobserved heterogeneity term to 0 . 
Table 7: Marginal Effects From Models with Interactions (Women), Model with Fixed-Effects Employment-

Population Ratio Employment Rate

15-24 25-64 $\quad 25-64$

\section{Estimation by Level of Education}

\begin{tabular}{lrrrr} 
Drop Out & $0.41^{* *}$ & $0.35^{* * *}$ & $0.35^{* * *}$ & 0.22 \\
& $(0.20)$ & $(0.14)$ & $(0.10)$ & $(0.20)$ \\
Short prof Tracks & $0.38^{* *}$ & $0.44^{* * *}$ & $0.40^{* * *}$ & $0.51^{* *}$ \\
& $(0.17)$ & $(0.15)$ & $(0.12)$ & $(0.21)$ \\
High School graduate & 0.12 & 0.06 & 0.07 & -0.03 \\
& $(0.13)$ & $(0.10)$ & $(0.07)$ & $(0.15)$ \\
Community College & -0.08 & -0.14 & $-0.11^{*}$ & -0.27 \\
College & $(0.08)$ & $(0.10)$ & $(0.06)$ & $(0.21)$ \\
& $0.30^{* *}$ & 0.10 & -0.01 & 0.10 \\
Higher & $(0.13)$ & $(0.09)$ & $(0.06)$ & $(0.14)$ \\
& -0.02 & 0.10 & -0.02 & 0.01 \\
& $(0.11)$ & $(0.09)$ & $(0.06)$ & $(0.15)$ \\
\hline
\end{tabular}

Estimation by Parents' Migration Status

\begin{tabular}{lrrrr} 
Native French parents & $0.17^{* *}$ & $0.14^{* *}$ & $0.12^{* * *}$ & 0.10 \\
& $(0.08)$ & $(0.06)$ & $(0.05)$ & $(0.08)$ \\
One immigrant (other) & 0.04 & 0.24 & 0.06 & 0.21 \\
& $(0.20)$ & $(0.16)$ & $(0.14)$ & $(0.21)$ \\
One African immigrant & 0.02 & 0.16 & 0.07 & 0.02 \\
& $(0.19)$ & $(0.15)$ & $(0.13)$ & $(0.19)$ \\
\hline
\end{tabular}

Estimation by Living Arrangement when leaving school

$\begin{array}{lrrrr}\text { Parental home } & 0.15 & 0.13 & 0.10 & 0.05 \\ \text { Living in couple } & (0.10) & (0.08) & (0.06) & (0.11) \\ & 0.18 & 0.25^{* *} & 0.20^{* *} & 0.22 \\ \text { Single } & (0.11) & (0.10) & (0.08) & (0.15) \\ & 0.09 & 0.16 & 0.04 & 0.25 \\ \text { N } & (0.13) & (0.13) & (0.11) & (0.19) \\ & 10874 & 10874 & 10874 & 10874\end{array}$

Note: Source: Generation 98 and Generation 04. All estimations include controls for education, age, past mobility, living arrangement, and parental characteristics. Standard errors are in parenthesis. ${ }^{*} p<0.1,{ }^{* *}$ $p<0.05,{ }^{* * *} p<0.01$ Column names indicate the rate use as explanatory variable. Exogenous model (Exo.) was estimated using logit models, and Fixed effect estimates(FE) were obtained using a conditional logit models. In the case of FE models, marginal effects were obtained by fixing the unobserved heterogeneity term to 0 . 
network outside their neighbourhood. As a consequence, labour market integration may be highly dependent to interpersonal relationships for these individuals, and neighbours are likely to play an important role in that respect. Conversely, we can interpret these effects as an attenuation of the local effect when education increases: higher diplomas may signal skills and motivation to employers, or more educated people maybe less subject to local social norms.

These effects are similar for women, but are not limited to high-school dropouts. Indeed young women with high-school vocational education ("short professional tracks") are also subject to the influence of the local employment rates during their labour market transitions, and their sensitivity may be even higher than the one of women high-school dropouts. This difference between gender may be explained by the qualitative difference between men and women vocational education that we do not take into account here: at that level of education, males tend to be trained for more technical jobs, than women who are more often enrolled in degrees related to services where skills may be harder to signal through the sole diploma.

\subsection{Parents' Migration Status}

Immigrants are more likely to develop and maintain cross-border ties with their country of origin (Waldinger (2015)). While maintaining these links with foreign places, their life in France might be more strongly related to the immediate neighbourhood they settled in. ${ }^{25}$ Although they are born in France, the children of immigrants might be affected by the very local dimension of the social network developed by their parents. That is why we conduct heterogeneity analysis by migration status of the parents, which results are presented in the second panel of Tables 6 and 7 .

The results show that the effect for individuals with French origins is fairly similar to the one found over the whole population with a marginal effect ranging from .14 to .19 for men, and from .10 to .17 for women. However, for young men with at least one parent born in Africa, the effect tend to be systematically higher, reaching .29 in the case of the 15-24 ER (Tab.6). Its lower significance level is only due to larger standard errors, this subgroup being the smallest (only $8 \%$ of the population). As to females, the same type of result emerges, but only for second generation immigrants of other origin and for the 25-64 category. These results suggest the higher importance of local peers or models for second generation immigrants.

\footnotetext{
${ }^{25}$ They may choose to live close to the acquaintances they initially had in their country of origin, their social network in France is likely to begin from that very specific place.
} 


\subsection{Living Arrangements when Leaving School and Labour Market Transition}

The analysis by type of living arrangement when leaving school is also of interest. Indeed, individuals who already left the parental home during their educational path may live in different areas than the ones where they actually grew up. So this variable gives us the opportunity to see the heterogeneity of effects for individuals whose links with the local community may be quite different.

Interestingly, we can see that these effects differ by gender. Young men are much more sensitive to the context when they are living with their parents just before their labour market transition. Among this subgroup, many men have lived in the same location for a long time (sometime since birth) giving them the opportunity to develop stronger links with their neighbours. Marginal effect ranges from .15 to .21 (Tab. 6, third panel).

On the contrary, for women, we find no impact of the local context when they are living with their parents just before the end of their education. But immediate neighbours do have an impact on women when they are living together with someone (partnered women): the marginal effect of the employment-population ratio even reaches a quarter point. It may reflect that once women are in couple, their labour supply might be more sensitive to local social norms.

\section{Conclusion}

This paper has studied the effect of local employment rate on labour market transitions. In particular, we have tested the hypothesis that young workers are influenced by social interactions and contextual effects in their close neighbourhood. Using a neighbourhood fixed-effect strategy, we find that the local employment rate at the block-group level does matter for individual transitions from school to work. We show that this effect is robust to the definition of the employment rate, and the inclusion of additional local characteristics of the population in the specification.

Depending on the specification, our estimates show that a one percentage point increase in the employment rate in the block-group (IRIS) where an individual lives when leaving school increases the chances of being employed three years after their transition to the labour market by .09 to .14 percentage points. This impact is generally larger for men (from .13 to .18) than women (from .09 to .15). One striking result shows that men and women respond to their 
gender-specific employment rate: men react to the local male employment rates and women to the female rates, and we find no response to changes in the opposite sex employment rates. Although this pattern may result from a gender segregation on the labour market that we would not capture in our covariates, this result suggests that same sex peers matter more than opposite sex ones.

Further analysis highlights the importance to move beyond, and to capture the heterogeneity of the effect: the intensity and even the existence of this effect depend on the characteristics of each individual. In terms of education, high-school dropouts appear to be very dependent of social interactions, a one percentage point increase in the employment rate being related to an increase in the probability of getting a job by more than 0.25 points for men and .22 for women, with marginal effects reaching values higher than .4 when considering the employmentpopulation ratio of young people. On the contrary, having a diploma makes individuals less sensitive to the local context. Men who still live with their parents at the moment when they leave school also appear to be more exposed to the context, as well as men of African origin. As to women, being part of a couple seems to be an important additional factor. And second generation immigrants of other origin tend to be more sensitive to the level of employment of their elders.

These results demonstrate the importance of the local context on individual transition from school to work. They also highlight the gender dimension of these effects. The size of our results can be compared to the direct effect of education. From our estimates, we can note that compared to high-school dropouts, the probability of getting a job for individuals who have short professional tracks, or high-school degrees is higher by 13 to 16 percentage-point. ${ }^{26}$ So, the impact of education may be dual since it directly increases the probability of getting a job, and makes individuals less sensitive to the local context. Finally, the local effects we find have to be linked to the existence of a local social equilibrium (see Brock and Durlauf (2001)), that has important implications in terms of public policies: the social equilibrium could constitute a feedback force that has to be taken into account in order to durably change local employment rates, and reduce the geographical dispersion of employment rates over the territory.

\footnotetext{
${ }^{26}$ Marginal effects of education are given in Table 11 of the appendix. Note that the interpretation of the marginal effect in this case of a discrete variable is slightly different from the one of employment rates. In the case of education, a .13 coefficient in the table corresponds to a increase in employment probability of 13 percentage point, whereas in the previous analysis, a .13 coefficient was associated to a .13 percentage point increase in the probability of employment.
} 


\section{A Spatial Correlation and Neighbourhoods}

Moran indices are designed to capture spatial autocorrelation in a variable $X$ between the $N$ units belonging to the same geographical area. The distance between two distinct units $i$ and $j$ is denoted $w_{i j}$, and the Moran index for that given geographical area is:

$$
I=\frac{N}{\sum_{i} \sum_{j} w_{i j}} \frac{\sum_{i} \sum_{j} w_{i j}\left(X_{i}-\bar{X}\right)\left(X_{j}-\bar{X}\right)}{\sum_{i}\left(X_{i}-\bar{X}\right)^{2}}
$$

In our case, the units are block-groups (Iris), and we use the inverse of the euclidean distance between centroids as the weight between two units. Moran statistics are then standardized, the standardized value being compared to the quantiles of the normal distribution to test for the presence of autocorrelation.

From the census we restricted the sample of neighbourhoods to the ones that contain more than 3 block-groups, which restrict our sample to 1,464 neighbourhoods containing 10,099 block-groups. This restriction is due to the necessity to have at least 4 units to compute the test statistic. As a consequence, the sample used here is not exactly representative of our estimation sample, which also contains neighbourhoods with less than 4 block-groups.

Table 8 shows the results of such tests for several variables taken from the 1999 census. The standardized statistics were computed at three different levels: the neighbourhood level, the municipality level, and the urban unit level. For each geographical level, the first column gives the share of tests statistics that do not reject the null hypothesis of the absence of spatial autocorrelation. We can see from this table that the smaller the area, the larger the share of non-rejections. At the neighbourhood level, we find rejections rates that are close to $5 \%$ in particular for variables like employment rate, or employed over population ratios.

One concern that may arise is that areas with different size have a different number of blockgroups, which makes the comparison subject to caution despite the standardization. Indeed, normality is an asymptotic property of the Moran index (see Cliff and Ord (1981)), and many of the neighbourhoods we consider are composed of less than 4 block-groups. To make progress regarding this concern we also give information about the share of indices that are below 0 for each geographical level (second column gives), since a lower spatial correlation should also lead to a more symmetric distribution of statistics. Although the distribution is not perfectly symmetric for any of the variables, again we see that the neighbourhood level seems much less subject to spatial autocorrelation, so the change in the rejection rates is not a pure artefact of 
the size of the considered areas. 
Table 8: Moran Test of Spatial Autocorrelation between Block-groups

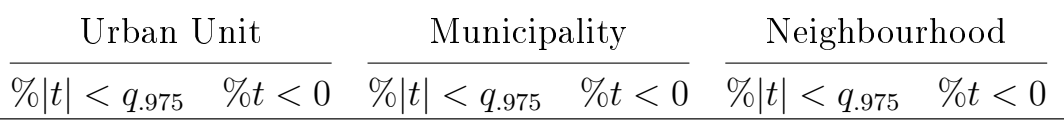

Population composition

Total Population

$\%$ of Students

$\%$ aged $0-19$

$\%$ aged $20-39$

$\%$ aged $40-59$

Place of Birth

$\%$ Born in the Department

$\%$ Born in the Region

\% Born in France

Population aged 30-39

Number of Individuals

$\%$ No dipl.

$\%$ Primary Ed.

$\%$ Middle School degree (BEPC)

$\%$ Short Prof. Tracks (BEP-CAP)

$\%$ High School Degree (BAC)

\% Some College (DEUG)

$\%$ Higher degree

Population aged 40 or more

Number of Individuals

$\%$ No dipl.

$\%$ Primary Ed.

$\%$ Middle School degree (BEPC)

$\%$ Short Prof. Tracks (BEP-CAP)

$\%$ High School Degree (BAC)

$\%$ Some College (DEUG)

$\%$ Higher degree

$\begin{array}{llllll}0.88 & 0.31 & 0.94 & 0.41 & 0.96 & 0.43 \\ 0.77 & 0.31 & 0.86 & 0.32 & 0.93 & 0.37 \\ 0.67 & 0.23 & 0.81 & 0.31 & 0.91 & 0.39 \\ 0.73 & 0.31 & 0.87 & 0.39 & 0.93 & 0.42 \\ 0.69 & 0.19 & 0.87 & 0.32 & 0.93 & 0.38\end{array}$

$\begin{array}{llllll}0.56 & 0.15 & 0.79 & 0.29 & 0.91 & 0.36 \\ 0.60 & 0.16 & 0.82 & 0.30 & 0.92 & 0.35 \\ 0.65 & 0.26 & 0.82 & 0.31 & 0.92 & 0.37\end{array}$

$\begin{array}{llllll}0.88 & 0.34 & 0.93 & 0.40 & 0.96 & 0.43 \\ 0.71 & 0.28 & 0.83 & 0.33 & 0.91 & 0.39 \\ 0.81 & 0.31 & 0.88 & 0.35 & 0.95 & 0.42 \\ 0.90 & 0.41 & 0.94 & 0.44 & 0.96 & 0.47 \\ 0.70 & 0.25 & 0.84 & 0.35 & 0.92 & 0.40 \\ 0.79 & 0.34 & 0.89 & 0.37 & 0.94 & 0.45 \\ 0.73 & 0.28 & 0.83 & 0.34 & 0.93 & 0.40 \\ 0.63 & 0.21 & 0.78 & 0.28 & 0.89 & 0.35\end{array}$

Employment population ratios

\begin{tabular}{|c|c|c|c|c|c|c|}
\hline $15-24$ & 0.75 & 0.29 & 0.85 & 0.37 & 0.93 & 0.45 \\
\hline $25-64$ & 0.71 & 0.25 & 0.84 & 0.33 & 0.92 & 0.41 \\
\hline $15-64$ & 0.71 & 0.25 & 0.83 & 0.34 & 0.92 & 0.39 \\
\hline \multicolumn{7}{|c|}{ Employment rates } \\
\hline $15-24$ & 0.78 & 0.34 & 0.88 & 0.36 & 0.94 & 0.42 \\
\hline $25-64$ & 0.66 & 0.21 & 0.84 & 0.35 & 0.93 & 0.41 \\
\hline $15-64$ & 0.66 & 0.22 & 0.84 & 0.34 & 0.93 & 0.39 \\
\hline Units & \multirow{2}{*}{\multicolumn{2}{|c|}{$\begin{array}{c}356 \\
15.409\end{array}$}} & \multirow{2}{*}{\multicolumn{2}{|c|}{$\begin{array}{c}975 \\
10099\end{array}$}} & \multicolumn{2}{|c|}{1,464} \\
\hline Block-groups & & & & & 10,09 & \\
\hline
\end{tabular}

Notes: All statistics were computed from the 1999 Census. For each geographical level, Moran tests statistics of spatial autocorrelation between block-groups (IRIS) were computed. The first level gives the share of standardized Moran statistics that were below the 97.5 percentile of the standard normal distribution. The second column gives the share of the same set of statistics that are below 0 . 


\section{B Controlling for Additional Local Characteristics}

The block-group level analysis developed in this paper highlights the effect of the local employment ratios. Despite the small size of these residential areas, the local differences in the labour market integration might also be due to other contextual variables. The initial estimated effects could reflect other neighbourhood effects than local interaction effects.

By including neighbourhood fixed effects, we control for all characteristics defined at the neighbourhood level. Given the dimensions of the neighbourhoods, the common characteristics might include any effect due to spatial mismatch or redlining effects. Infra-neighbourhood change in blocks characteristics may however bias the analysis if they are linked to both individual heterogeneity and employment rate in the blocks.

Contextual variables are added to the initial regressions using additional census data information about the composition of census-blocks: type of housing (share of public housing, share of single-detached dwellings), share of owner-occupiers, residents turnover (proportion of residents in the block since at least 5 years / arrived during the two last years), transport mode used (car owner ratio, public transportation ratio) and the social composition of the block (ratio executive/white and blue collar, proportion of people without diploma, share of one parent family, immigrant-to-population ratio).

All these contextual characteristics are summarized into three variables using principal component analysis (PCA). As we have many contextual variables that are highly correlated, this strategy enables us to reduce the dimension of the data while maintaining enough information to control for most of the neighbourhood characteristics. The three first axes of the principal component analysis account for three-quarters of the total variance of the 11 continuous variables used for the analysis. The first axis splits block-groups according to the type of housing (high rate of public housing in the positive part versus high rate of single-detached dwelling owners in the negative part). The social composition of the block-groups is projected on the second axis: areas with high proportions of executives and newcomers (in the block since for less than 2 years) are on the negative part whereas areas with the highest levels of residents who have been living in the blocks for at least 5 years, and those without any diploma are on the positive part. The positive part of the third axis mainly distinguishes areas where residents are mainly immobile, executives and individuals who use public transportation. 
C Full set of estimates 
Table 9: Detailed Estimates of the Baseline Model

\begin{tabular}{|c|c|c|c|c|c|c|c|c|}
\hline & \multicolumn{4}{|c|}{ Employment-Population Ratio } & \multicolumn{4}{|c|}{ Employment Rate } \\
\hline & \multicolumn{2}{|c|}{$15-24$} & \multicolumn{2}{|c|}{$25-64$} & \multicolumn{2}{|c|}{$15-24$} & \multicolumn{2}{|c|}{$25-64$} \\
\hline & Exo. & $\mathrm{FE}$ & Exo. & $\mathrm{FE}$ & Exo. & $\mathrm{FE}$ & Exo. & $\mathrm{FE}$ \\
\hline Rate & $\begin{array}{r}1.034^{* * *} \\
(0.212)\end{array}$ & $\begin{array}{r}0.471 \\
(0.301)\end{array}$ & $\begin{array}{r}0.836^{* * *} \\
(0.176)\end{array}$ & $\begin{array}{r}0.904^{* * *} \\
(0.313)\end{array}$ & $\begin{array}{r}0.825^{* * *} \\
(0.143)\end{array}$ & $\begin{array}{r}0.735^{* * *} \\
(0.224)\end{array}$ & $\begin{array}{r}1.376^{* * *} \\
(0.230)\end{array}$ & $\begin{array}{r}0.956^{* *} \\
(0.381)\end{array}$ \\
\hline \multicolumn{9}{|l|}{ Education } \\
\hline High-school drop outs & ref. & ref. & ref. & ref. & ref. & ref. & ref. & ref. \\
\hline Short professional tracks & $\begin{array}{r}0.663^{* * *} \\
(0.048)\end{array}$ & $\begin{array}{r}0.659^{* * *} \\
(0.051)\end{array}$ & $\begin{array}{r}0.658^{* * *} \\
(0.048)\end{array}$ & $\begin{array}{r}0.656^{* * *} \\
(0.051)\end{array}$ & $\begin{array}{r}0.657^{* * *} \\
(0.048)\end{array}$ & $\begin{array}{r}0.656^{* * *} \\
(0.051)\end{array}$ & $\begin{array}{r}0.655^{* * *} \\
(0.048)\end{array}$ & $\begin{array}{r}0.656^{* * *} \\
(0.051)\end{array}$ \\
\hline General high-school & $\begin{array}{r}0.646^{* * *} \\
(0.059)\end{array}$ & $\begin{array}{r}0.655^{* * *} \\
(0.062)\end{array}$ & $\begin{array}{r}0.631^{* * *} \\
(0.059)\end{array}$ & $\begin{array}{r}0.653^{* * *} \\
(0.062)\end{array}$ & $\begin{array}{r}0.626^{* * *} \\
(0.059)\end{array}$ & $\begin{array}{r}0.648^{* * *} \\
(0.062)\end{array}$ & $\begin{array}{r}0.633^{* * *} \\
(0.059)\end{array}$ & $\begin{array}{r}0.653^{* * *} \\
(0.062)\end{array}$ \\
\hline Community College & $\begin{array}{r}1.797^{* * * *} \\
(0.084)\end{array}$ & $\begin{array}{r}1.759^{* * *} \\
(0.087)\end{array}$ & $\begin{array}{r}1.774^{* * *} \\
(0.084)\end{array}$ & $\begin{array}{r}1.756^{* * *} \\
(0.087)\end{array}$ & $\begin{array}{r}1.765^{* * *} \\
(0.084)\end{array}$ & $\begin{array}{r}1.749^{* * *} \\
(0.088)\end{array}$ & $\begin{array}{r}1.773^{* * *} \\
(0.084)\end{array}$ & $\begin{array}{r}1.755^{* * *} \\
(0.087)\end{array}$ \\
\hline College & $\begin{array}{r}1.080^{* * *} \\
(0.098)\end{array}$ & $\begin{array}{r}1.066^{* * *} \\
(0.104)\end{array}$ & $\begin{array}{r}1.049^{* * *} \\
(0.098)\end{array}$ & $\begin{array}{r}1.062^{* * *} \\
(0.104)\end{array}$ & $\begin{array}{r}1.035^{* * *} \\
(0.098)\end{array}$ & $\begin{array}{r}1.054^{* * *} \\
(0.104)\end{array}$ & $\begin{array}{r}1.056^{* * *} \\
(0.098)\end{array}$ & $\begin{array}{r}1.062^{* * *} \\
(0.104)\end{array}$ \\
\hline Higher Graduate & $\begin{array}{r}1.476^{* * *} \\
(0.109)\end{array}$ & $\begin{array}{r}1.463^{* * *} \\
(0.116)\end{array}$ & $\begin{array}{r}1.431^{* * *} \\
(0.109)\end{array}$ & $\begin{array}{r}1.461^{* * *} \\
(0.116)\end{array}$ & $\begin{array}{r}1.411^{* * *} \\
(0.109)\end{array}$ & $\begin{array}{r}1.451^{* * *} \\
(0.116)\end{array}$ & $\begin{array}{r}1.444^{* * *} \\
(0.109)\end{array}$ & $\begin{array}{r}1.460^{* * *} \\
(0.116)\end{array}$ \\
\hline Repeated a year in primary school & $\begin{array}{r}0.136^{* * *} \\
(0.044)\end{array}$ & $\begin{array}{r}0.159^{* * *} \\
(0.046)\end{array}$ & $\begin{array}{r}0.135^{* * *} \\
(0.044)\end{array}$ & $\begin{array}{r}0.159^{* * *} \\
(0.046)\end{array}$ & $\begin{array}{r}0.136^{* * *} \\
(0.044)\end{array}$ & $\begin{array}{r}0.160^{* * *} \\
(0.046)\end{array}$ & $\begin{array}{r}0.135^{* * *} \\
(0.044)\end{array}$ & $\begin{array}{r}0.160^{* * *} \\
(0.046)\end{array}$ \\
\hline Age diff. wrt Average age in the diploma & $\begin{array}{r}-0.064^{* * *} \\
(0.016)\end{array}$ & $\begin{array}{r}-0.066^{* * *} \\
(0.017)\end{array}$ & $\begin{array}{r}-0.063^{* * *} \\
(0.016)\end{array}$ & $\begin{array}{r}-0.067^{* * *} \\
(0.017)\end{array}$ & $\begin{array}{r}-0.061^{* * *} \\
(0.016)\end{array}$ & $\begin{array}{r}-0.066^{* * *} \\
(0.017)\end{array}$ & $\begin{array}{r}-0.065^{* * *} \\
(0.016)\end{array}$ & $\begin{array}{r}-0.067^{* * *} \\
(0.017)\end{array}$ \\
\hline \multicolumn{9}{|l|}{ Living Arrangement when leaving school } \\
\hline Parental home & ref. & ref. & ref. & ref. & ref. & ref. & ref. & ref. \\
\hline Living in couple & $\begin{array}{r}0.152^{* * *} \\
(0.051)\end{array}$ & $\begin{array}{r}0.201^{* * *} \\
(0.054)\end{array}$ & $\begin{array}{r}0.157^{* * *} \\
(0.051)\end{array}$ & $\begin{array}{r}0.200^{* * *} \\
(0.054)\end{array}$ & $\begin{array}{r}0.157^{* * *} \\
(0.051)\end{array}$ & $\begin{array}{r}0.201^{* * *} \\
(0.054)\end{array}$ & $\begin{array}{r}0.159^{* * *} \\
(0.051)\end{array}$ & $\begin{array}{r}0.202^{* * *} \\
(0.054)\end{array}$ \\
\hline Single & $\begin{array}{r}-0.022 \\
(0.050)\end{array}$ & $\begin{array}{r}0.016 \\
(0.053)\end{array}$ & $\begin{array}{r}-0.022 \\
(0.050)\end{array}$ & $\begin{array}{r}0.015 \\
(0.053)\end{array}$ & $\begin{array}{r}-0.027 \\
(0.050)\end{array}$ & $\begin{array}{r}0.016 \\
(0.053)\end{array}$ & $\begin{array}{r}-0.019 \\
(0.050)\end{array}$ & $\begin{array}{r}0.017 \\
(0.053)\end{array}$ \\
\hline \multicolumn{9}{|l|}{ Parents' Occupation } \\
\hline Blue/white-collar & ref. & ref. & ref. & ref. & ref. & ref. & ref. & ref. \\
\hline \multirow[t]{2}{*}{ Intermediate } & 0.060 & 0.062 & 0.050 & 0.060 & 0.050 & 0.060 & 0.046 & 0.059 \\
\hline & $(0.056)$ & $(0.058)$ & $(0.056)$ & $(0.058)$ & $(0.056)$ & $(0.058)$ & $(0.056)$ & $(0.058)$ \\
\hline Executive & $\begin{array}{r}-0.108^{* *} \\
(0.043)\end{array}$ & $\begin{array}{r}-0.058 \\
(0.046)\end{array}$ & $\begin{array}{r}-0.137^{* * *} \\
(0.043)\end{array}$ & $\begin{array}{r}-0.063 \\
(0.046)\end{array}$ & $\begin{array}{r}-0.140^{* * *} \\
(0.043)\end{array}$ & $\begin{array}{r}-0.062 \\
(0.046)\end{array}$ & $\begin{array}{r}-0.136^{* * *} \\
(0.043)\end{array}$ & $\begin{array}{r}-0.062 \\
(0.046)\end{array}$ \\
\hline Craftsman & $\begin{array}{r}0.008 \\
(0.050)\end{array}$ & $\begin{array}{r}0.043 \\
(0.052)\end{array}$ & $\begin{array}{r}-0.001 \\
(0.050)\end{array}$ & $\begin{array}{r}0.040 \\
(0.052)\end{array}$ & $\begin{array}{c}-0.008 \\
(0.050)\end{array}$ & $\begin{array}{r}0.039 \\
(0.052)\end{array}$ & $\begin{array}{r}-0.002 \\
(0.050)\end{array}$ & $\begin{array}{r}0.041 \\
(0.052)\end{array}$ \\
\hline \multicolumn{9}{|l|}{ Parents' Employment Status } \\
\hline Two working parents & ref. & ref. & ref. & ref. & ref. & ref. & ref. & ref. \\
\hline One working parent & $\begin{array}{r}-0.209^{* * *} \\
(0.035)\end{array}$ & $\begin{array}{r}-0.190^{* * *} \\
(0.038)\end{array}$ & $\begin{array}{r}-0.195^{* * *} \\
(0.036)\end{array}$ & $\begin{array}{r}-0.186^{* * *} \\
(0.038)\end{array}$ & $\begin{array}{r}-0.193^{* * *} \\
(0.036)\end{array}$ & $\begin{array}{r}-0.186^{* * *} \\
(0.038)\end{array}$ & $\begin{array}{r}-0.194^{* * *} \\
(0.036)\end{array}$ & $\begin{array}{r}-0.186^{* * *} \\
(0.038)\end{array}$ \\
\hline One former worker & $\begin{array}{r}-0.275^{* * *} \\
(0.046)\end{array}$ & $\begin{array}{r}-0.280^{* * *} \\
(0.049)\end{array}$ & $\begin{array}{r}-0.260^{* * *} \\
(0.047)\end{array}$ & $\begin{array}{r}-0.276^{* * *} \\
(0.049)\end{array}$ & $\begin{array}{r}-0.261^{* * *} \\
(0.046)\end{array}$ & $\begin{array}{r}-0.276^{* * *} \\
(0.049)\end{array}$ & $\begin{array}{r}-0.258^{* * *} \\
(0.047)\end{array}$ & $\begin{array}{r}-0.276^{* * *} \\
(0.049)\end{array}$ \\
\hline Never worked/unknown parents & $\begin{array}{r}-0.708^{* * *} \\
(0.137)\end{array}$ & $\begin{array}{r}-0.647^{* * *} \\
(0.146)\end{array}$ & $\begin{array}{r}-0.693^{* * *} \\
(0.137)\end{array}$ & $\begin{array}{r}-0.639^{* * *} \\
(0.146)\end{array}$ & $\begin{array}{r}-0.692^{* * *} \\
(0.137)\end{array}$ & $\begin{array}{r}-0.639^{* * *} \\
(0.146)\end{array}$ & $\begin{array}{r}-0.685^{* * *} \\
(0.138)\end{array}$ & $\begin{array}{r}-0.641^{* * *} \\
(0.146)\end{array}$ \\
\hline \multicolumn{9}{|l|}{ Parents' Migration Status } \\
\hline Native French parents & ref. & ref. & ref. & ref. & ref. & ref. & ref. & ref. \\
\hline One African immigrant & $\begin{array}{r}-0.363^{* * *} \\
(0.048)\end{array}$ & $\begin{array}{r}-0.410^{* * *} \\
(0.054)\end{array}$ & $\begin{array}{r}-0.342^{* * *} \\
(0.048)\end{array}$ & $\begin{array}{r}-0.393^{* * *} \\
(0.054)\end{array}$ & $\begin{array}{r}-0.345^{* * *} \\
(0.048)\end{array}$ & $\begin{array}{r}-0.397^{* * *} \\
(0.054)\end{array}$ & $\begin{array}{r}-0.313^{* * *} \\
(0.049)\end{array}$ & $\begin{array}{r}-0.394^{* * *} \\
(0.054)\end{array}$ \\
\hline One immigrant (other) & $\begin{array}{r}0.055 \\
(0.057)\end{array}$ & $\begin{array}{r}0.020 \\
(0.061)\end{array}$ & $\begin{array}{r}0.066 \\
(0.057)\end{array}$ & $\begin{array}{r}0.026 \\
(0.061)\end{array}$ & $\begin{array}{r}0.057 \\
(0.057)\end{array}$ & $\begin{array}{r}0.023 \\
(0.061)\end{array}$ & $\begin{array}{r}0.077 \\
(0.057)\end{array}$ & $\begin{array}{r}0.027 \\
(0.061)\end{array}$ \\
\hline Same Municipality since 6 th grade & $\begin{array}{r}-0.427^{* *} \\
(0.190)\end{array}$ & $\begin{array}{r}-0.509^{* *} \\
(0.199)\end{array}$ & $\begin{array}{r}-0.419 * * \\
(0.189)\end{array}$ & $\begin{array}{r}-0.498^{* *} \\
(0.199)\end{array}$ & $\begin{array}{r}-0.427^{* *} \\
(0.189)\end{array}$ & $\begin{array}{r}-0.509^{* *} \\
(0.199)\end{array}$ & $\begin{array}{r}-0.411^{* *} \\
(0.189)\end{array}$ & $\begin{array}{r}-0.502^{* *} \\
(0.199)\end{array}$ \\
\hline Immobility duration (years) & $\begin{array}{r}0.034^{* *} \\
(0.016)\end{array}$ & $\begin{array}{r}0.038^{* *} \\
(0.017)\end{array}$ & $\begin{array}{r}0.034^{* *} \\
(0.016)\end{array}$ & $\begin{array}{r}0.037^{* *} \\
(0.017)\end{array}$ & $\begin{array}{r}0.036^{* *} \\
(0.016)\end{array}$ & $\begin{array}{c}0.038^{* *} \\
(0.017)\end{array}$ & $\begin{array}{r}0.032^{* *} \\
(0.016)\end{array}$ & $\begin{array}{r}0.037^{* *} \\
(0.017)\end{array}$ \\
\hline End of education in 2004 & $\begin{array}{r}-0.495^{* * *} \\
(0.041)\end{array}$ & $\begin{array}{r}-0.453^{* * *} \\
(0.049)\end{array}$ & $\begin{array}{r}-0.384^{* * *} \\
(0.032)\end{array}$ & $\begin{array}{r}-0.408^{* * *} \\
(0.035)\end{array}$ & $\begin{array}{r}-0.403^{* * *} \\
(0.033)\end{array}$ & $\begin{array}{r}-0.424^{* * *} \\
(0.035)\end{array}$ & $\begin{array}{r}-0.406^{* * *} \\
(0.033)\end{array}$ & $\begin{array}{r}-0.418^{* * *} \\
(0.035)\end{array}$ \\
\hline Sex & $\begin{array}{r}0.469 * * * \\
(0.032)\end{array}$ & $\begin{array}{r}0.460^{* * *} \\
(0.033)\end{array}$ & $\begin{array}{r}0.465^{* * *} \\
(0.032)\end{array}$ & $\begin{array}{r}0.458^{* * *} \\
(0.033)\end{array}$ & $\begin{array}{r}0.466^{* * *} \\
(0.032)\end{array}$ & $\begin{array}{r}0.459^{* * *} \\
(0.033)\end{array}$ & $\begin{array}{r}0.463^{* * *} \\
(0.032)\end{array}$ & $\begin{array}{r}0.458^{* * *} \\
(0.033)\end{array}$ \\
\hline Intercept & $\begin{array}{r}0.360^{* * *} \\
(0.102)\end{array}$ & & $\begin{array}{r}0.014 \\
(0.149)\end{array}$ & & $\begin{array}{l}-0.017 \\
(0.138)\end{array}$ & & $\begin{array}{r}-0.600^{* * *} \\
(0.217)\end{array}$ & \\
\hline $\mathrm{N}$ & 26,751 & 26,751 & 26,751 & 26,751 & 26,751 & 26,751 & 26,751 & 26,751 \\
\hline
\end{tabular}

Note: Source: Generation surveys (1998 and 2004). Standard errors are in parenthesis. ${ }^{*} p<0.1,{ }^{* *} p<0.05,{ }^{* * *} p<0.01$. Exogenous model (Exo.) was estimated using logit models, and Fixed effect estimates(FE) were obtained using a conditional logit models. 
Table 10: Detailed Estimates of the Model Controlling for Additional Characteristics

\begin{tabular}{|c|c|c|c|c|c|c|c|c|}
\hline & \multicolumn{4}{|c|}{ Employment-Population Ratio } & \multicolumn{4}{|c|}{ Employment Rate } \\
\hline & \multicolumn{2}{|c|}{$15-24$} & \multicolumn{2}{|c|}{$25-64$} & \multicolumn{2}{|c|}{$15-24$} & \multicolumn{2}{|c|}{$25-64$} \\
\hline & Exo. & $\mathrm{FE}$ & Exo. & $\mathrm{FE}$ & Exo. & $\mathrm{FE}$ & Exo. & $\mathrm{FE}$ \\
\hline Rate & $\begin{array}{r}1.171^{* * *} \\
(0.214)\end{array}$ & $\begin{array}{r}0.491 \\
(0.321)\end{array}$ & $\begin{array}{r}1.549^{* * *} \\
(0.223)\end{array}$ & $\begin{array}{r}1.093^{* * *} \\
(0.403)\end{array}$ & $\begin{array}{r}1.491^{* * *} \\
(0.177)\end{array}$ & $\begin{array}{r}0.853^{* * *} \\
(0.261)\end{array}$ & $\begin{array}{r}2.771^{* * *} \\
(0.327)\end{array}$ & $\begin{array}{r}1.278^{* *} \\
(0.561)\end{array}$ \\
\hline \multicolumn{9}{|l|}{ Education } \\
\hline High-school dropouts & ref. & ref. & ref. & ref. & ref. & ref. & ref. & ref. \\
\hline Short professional tracks & $\begin{array}{r}0.665^{* * *} \\
(0.048)\end{array}$ & $\begin{array}{r}0.656^{* * *} \\
(0.051)\end{array}$ & $\begin{array}{r}0.663^{* * * *} \\
(0.048)\end{array}$ & $\begin{array}{r}0.657^{* * *} \\
(0.051)\end{array}$ & $\begin{array}{r}0.662^{* * *} \\
(0.048)\end{array}$ & $\begin{array}{r}0.656^{* * *} \\
(0.051)\end{array}$ & $\begin{array}{r}0.661^{* * *} \\
(0.048)\end{array}$ & $\begin{array}{r}0.656^{* * *} \\
(0.051)\end{array}$ \\
\hline General high-school & $\begin{array}{r}0.662^{* * *} \\
(0.059)\end{array}$ & $\begin{array}{r}0.654^{* * *} \\
(0.062)\end{array}$ & $\begin{array}{r}0.660^{* * *} \\
(0.059)\end{array}$ & $\begin{array}{r}0.656^{* * *} \\
(0.062)\end{array}$ & $\begin{array}{r}0.656^{* * *} \\
(0.059)\end{array}$ & $\begin{array}{r}0.650 * * * \\
(0.062)\end{array}$ & $\begin{array}{r}0.662^{* * *} \\
(0.059)\end{array}$ & $\begin{array}{r}0.656^{* * *} \\
(0.062)\end{array}$ \\
\hline Community College & $\begin{array}{r}1.817^{* * *} \\
(0.084)\end{array}$ & $\begin{array}{r}1.757^{* * *} \\
(0.088)\end{array}$ & $\begin{array}{r}1.810^{* * *} \\
(0.084)\end{array}$ & $\begin{array}{r}1.760^{* * *} \\
(0.088)\end{array}$ & $\begin{array}{r}1.801 * * * \\
(0.084)\end{array}$ & $\begin{array}{r}1.751^{* * *} \\
(0.088)\end{array}$ & $\begin{array}{r}1.807 * * * \\
(0.084)\end{array}$ & $\begin{array}{r}1.759^{* * *} \\
(0.088)\end{array}$ \\
\hline College & $\begin{array}{r}1.123^{* * *} \\
(0.099)\end{array}$ & $\begin{array}{r}1.067^{* * *} \\
(0.104)\end{array}$ & $\begin{array}{r}1.116^{* * *} \\
(0.099)\end{array}$ & $\begin{array}{r}1.069^{* * *} \\
(0.104)\end{array}$ & $\begin{array}{r}1.105^{* * *} \\
(0.099)\end{array}$ & $\begin{array}{r}1.060^{* * *} \\
(0.104)\end{array}$ & $\begin{array}{r}1.116^{* * *} \\
(0.099)\end{array}$ & $\begin{array}{r}1.068^{* * *} \\
(0.104)\end{array}$ \\
\hline Higher graduate & $\begin{array}{r}1.527 * * * \\
(0.111)\end{array}$ & $\begin{array}{r}1.465^{* * *} \\
(0.116)\end{array}$ & $\begin{array}{r}1.525^{* * *} \\
(0.111)\end{array}$ & $\begin{array}{r}1.469^{* * *} \\
(0.116)\end{array}$ & $\begin{array}{r}1.509^{* * *} \\
(0.111)\end{array}$ & $\begin{array}{r}1.458^{* * *} \\
(0.116)\end{array}$ & $\begin{array}{r}1.523^{* * *} \\
(0.111)\end{array}$ & $\begin{array}{r}1.469^{* * *} \\
(0.116)\end{array}$ \\
\hline Repeated a year in primary school & $\begin{array}{r}0.133^{* * *} \\
(0.044)\end{array}$ & $\begin{array}{r}0.158^{* * *} \\
(0.046)\end{array}$ & $\begin{array}{r}0.126^{* * *} \\
(0.044)\end{array}$ & $\begin{array}{r}0.157^{* * *} \\
(0.046)\end{array}$ & $\begin{array}{r}0.127^{* * *} \\
(0.044)\end{array}$ & $\begin{array}{r}0.158^{* * *} \\
(0.046)\end{array}$ & $\begin{array}{r}0.129^{* * *} \\
(0.044)\end{array}$ & $\begin{array}{r}0.158^{* * *} \\
(0.046)\end{array}$ \\
\hline Age diff. wrt Average age in the diploma & $\begin{array}{r}-0.070^{* * *} \\
(0.016)\end{array}$ & $\begin{array}{r}-0.067^{* * *} \\
(0.017)\end{array}$ & $\begin{array}{r}-0.071^{* * *} \\
(0.016)\end{array}$ & $\begin{array}{r}-0.068^{* * *} \\
(0.017)\end{array}$ & $\begin{array}{r}-0.070^{* * *} \\
(0.016)\end{array}$ & $\begin{array}{r}-0.067^{* * *} \\
(0.017)\end{array}$ & $\begin{array}{r}-0.071^{* * *} \\
(0.016)\end{array}$ & $\begin{array}{r}-0.068^{* * *} \\
(0.017)\end{array}$ \\
\hline Living Arrangement when leaving school & & & & & & & & \\
\hline Parental home & ref. & ref. & ref. & ref. & ref. & ref. & ref. & ref. \\
\hline Living in couple & $\begin{array}{r}0.168^{* * *} \\
(0.052)\end{array}$ & $\begin{array}{r}0.202 * * * \\
(0.054)\end{array}$ & $\begin{array}{r}0.170^{* * *} \\
(0.052)\end{array}$ & $\begin{array}{r}0.202^{* * *} \\
(0.054)\end{array}$ & $\begin{array}{r}0.174 * * * \\
(0.052)\end{array}$ & $\begin{array}{r}0.203^{* * *} \\
(0.054)\end{array}$ & $\begin{array}{r}0.173^{* * *} \\
(0.052)\end{array}$ & $\begin{array}{r}0.203^{* * *} \\
(0.054)\end{array}$ \\
\hline Single & $\begin{array}{r}0.007 \\
(0.051)\end{array}$ & $\begin{array}{r}0.017 \\
(0.053)\end{array}$ & $\begin{array}{r}0.011 \\
(0.051)\end{array}$ & $\begin{array}{r}0.017 \\
(0.053)\end{array}$ & $\begin{array}{r}0.008 \\
(0.051)\end{array}$ & $\begin{array}{r}0.018 \\
(0.053)\end{array}$ & $\begin{array}{r}0.011 \\
(0.051)\end{array}$ & $\begin{array}{r}0.018 \\
(0.053)\end{array}$ \\
\hline Parents' Occupation & & & & & & & & \\
\hline Blue/white-collar & ref. & ref. & ref. & ref. & ref. & ref. & ref. & ref. \\
\hline Intermediate & $\begin{array}{r}0.058 \\
(0.056)\end{array}$ & $\begin{array}{r}0.060 \\
(0.058)\end{array}$ & $\begin{array}{r}0.050 \\
(0.056)\end{array}$ & $\begin{array}{r}0.060 \\
(0.058)\end{array}$ & $\begin{array}{r}0.052 \\
(0.056)\end{array}$ & $\begin{array}{r}0.059 \\
(0.058)\end{array}$ & $\begin{array}{r}0.048 \\
(0.056)\end{array}$ & $\begin{array}{r}0.058 \\
(0.058)\end{array}$ \\
\hline Executive & $\begin{array}{r}-0.096^{* *} \\
(0.044)\end{array}$ & $\begin{array}{r}-0.057 \\
(0.046)\end{array}$ & $\begin{array}{r}-0.104^{* *} \\
(0.044)\end{array}$ & $\begin{array}{l}-0.057 \\
(0.046)\end{array}$ & $\begin{array}{r}-0.103^{* *} \\
(0.044)\end{array}$ & $\begin{array}{l}-0.057 \\
(0.046)\end{array}$ & $\begin{array}{r}-0.101^{* *} \\
(0.044)\end{array}$ & $\begin{array}{l}-0.058 \\
(0.046)\end{array}$ \\
\hline Craftsman & $\begin{array}{r}0.019 \\
(0.050)\end{array}$ & $\begin{array}{r}0.042 \\
(0.052)\end{array}$ & $\begin{array}{r}0.022 \\
(0.050)\end{array}$ & $\begin{array}{r}0.043 \\
(0.052)\end{array}$ & $\begin{array}{r}0.013 \\
(0.050)\end{array}$ & $\begin{array}{r}0.042 \\
(0.052)\end{array}$ & $\begin{array}{r}0.024 \\
(0.050)\end{array}$ & $\begin{array}{r}0.045 \\
(0.052)\end{array}$ \\
\hline Parents' Employment $S$ & & & & & & & & \\
\hline Two working parents & ref. & ref. & ref. & ref. & ref. & ref. & ref. & ref. \\
\hline One working parent & $\begin{array}{r}-0.209^{* * *} \\
(0.035)\end{array}$ & $\begin{array}{r}-0.187^{* * *} \\
(0.038)\end{array}$ & $\begin{array}{r}-0.191^{* * *} \\
(0.036)\end{array}$ & $\begin{array}{r}-0.185^{* * *} \\
(0.038)\end{array}$ & $\begin{array}{r}-0.191^{* * *} \\
(0.036)\end{array}$ & $\begin{array}{r}-0.185^{* * *} \\
(0.038)\end{array}$ & $\begin{array}{r}-0.190^{* * *} \\
(0.036)\end{array}$ & $\begin{array}{r}-0.186^{* * *} \\
(0.038)\end{array}$ \\
\hline One former worker & $\begin{array}{r}-0.274^{* * *} \\
(0.046)\end{array}$ & $\begin{array}{r}-0.277^{* * *} \\
(0.049)\end{array}$ & $\begin{array}{r}-0.257^{* * *} * \\
(0.047)\end{array}$ & $\begin{array}{r}-0.276^{* * *} \\
(0.049)\end{array}$ & $\begin{array}{r}-0.259^{* * *} \\
(0.047)\end{array}$ & $\begin{array}{r}-0.275^{* * *} \\
(0.049)\end{array}$ & $\begin{array}{r}-0.255^{* * *} \\
(0.047)\end{array}$ & $\begin{array}{r}-0.275^{* * *} \\
(0.049)\end{array}$ \\
\hline Never worked/unknown parents & $\begin{array}{r}-0.704^{* * *} \\
(0.137)\end{array}$ & $\begin{array}{r}-0.645^{* * *} \\
(0.146)\end{array}$ & $\begin{array}{r}-0.687^{* * *} \\
(0.138)\end{array}$ & $\begin{array}{r}-0.640^{* * *} \\
(0.146)\end{array}$ & $\begin{array}{r}-0.688^{* * *} \\
(0.138)\end{array}$ & $\begin{array}{r}-0.639^{* * *} \\
(0.146)\end{array}$ & $\begin{array}{r}-0.680^{* * *} \\
(0.138)\end{array}$ & $\begin{array}{r}-0.640^{* * *} \\
(0.146)\end{array}$ \\
\hline Parents' Migration Status & & & & & & & & \\
\hline Native French parents & ref. & ref. & ref. & ref. & ref. & ref. & ref. & ref. \\
\hline One African immigrant & $\begin{array}{r}-0.376^{* * *} \\
(0.050)\end{array}$ & $\begin{array}{r}-0.400^{* * *} \\
(0.054)\end{array}$ & $\begin{array}{r}-0.375^{* * *} \\
(0.050)\end{array}$ & $\begin{array}{r}-0.395^{* * *} \\
(0.054)\end{array}$ & $\begin{array}{r}-0.383^{* * *} \\
(0.050)\end{array}$ & $\begin{array}{r}-0.398^{* * *} \\
(0.054)\end{array}$ & $\begin{array}{r}-0.366^{* * *} \\
(0.051)\end{array}$ & $\begin{array}{r}-0.397^{* * *} \\
(0.054)\end{array}$ \\
\hline One immigrant (other) & $\begin{array}{r}0.050 \\
(0.058)\end{array}$ & $\begin{array}{r}0.024 \\
(0.061)\end{array}$ & $\begin{array}{r}0.055 \\
(0.058)\end{array}$ & $\begin{array}{r}0.028 \\
(0.061)\end{array}$ & $\begin{array}{r}0.041 \\
(0.058)\end{array}$ & $\begin{array}{r}0.025 \\
(0.061)\end{array}$ & $\begin{array}{r}0.055 \\
(0.058)\end{array}$ & $\begin{array}{r}0.028 \\
(0.061)\end{array}$ \\
\hline Same Municipality since 6 th grade & $\begin{array}{r}-0.423^{* *} \\
(0.190)\end{array}$ & $\begin{array}{r}-0.513^{* * *} \\
(0.199)\end{array}$ & $\begin{array}{r}-0.409^{* *} \\
(0.190)\end{array}$ & $\begin{array}{r}-0.503^{* *} \\
(0.199)\end{array}$ & $\begin{array}{r}-0.421^{* *} \\
(0.190)\end{array}$ & $\begin{array}{r}-0.516^{* * *} \\
(0.199)\end{array}$ & $\begin{array}{r}-0.417^{* *} \\
(0.190)\end{array}$ & $\begin{array}{r}-0.505^{* *} \\
(0.199)\end{array}$ \\
\hline Immobility duration (years) & $\begin{array}{c}0.029^{*} \\
(0.016)\end{array}$ & $\begin{array}{r}0.037^{* *} \\
(0.017)\end{array}$ & $\begin{array}{r}0.028^{*} \\
(0.016)\end{array}$ & $\begin{array}{r}0.037^{* *} \\
(0.017)\end{array}$ & $\begin{array}{c}0.029^{*} \\
(0.016)\end{array}$ & $\begin{array}{r}0.038^{* *} \\
(0.017)\end{array}$ & $\begin{array}{c}0.029^{*} \\
(0.016)\end{array}$ & $\begin{array}{r}0.037^{* *} \\
(0.017)\end{array}$ \\
\hline End of education in 2004 & $\begin{array}{r}-0.510^{* * *} \\
(0.041)\end{array}$ & $\begin{array}{r}-0.455^{* * *} \\
(0.051)\end{array}$ & $\begin{array}{r}-0.391^{* * *} \\
(0.032)\end{array}$ & $\begin{array}{r}-0.409^{* * *} \\
(0.035)\end{array}$ & $\begin{array}{r}-0.424^{* * *} \\
(0.033)\end{array}$ & $\begin{array}{r}-0.427^{* * *} \\
(0.036)\end{array}$ & $\begin{array}{r}-0.435^{* * *} \\
(0.033)\end{array}$ & $\begin{array}{r}-0.424^{* * *} \\
(0.036)\end{array}$ \\
\hline Sex & $\begin{array}{r}0.465^{* * *} \\
(0.032)\end{array}$ & $\begin{array}{r}0.459^{* * *} \\
(0.033)\end{array}$ & $\begin{array}{r}0.464^{* * *} \\
(0.032)\end{array}$ & $\begin{array}{r}0.459^{* * *} \\
(0.033)\end{array}$ & $\begin{array}{r}0.464^{* * *} \\
(0.032)\end{array}$ & $\begin{array}{r}0.459^{* * *} \\
(0.033)\end{array}$ & $\begin{array}{r}0.463^{* * *} \\
(0.032)\end{array}$ & $\begin{array}{r}0.458^{* * *} \\
(0.033)\end{array}$ \\
\hline Additional Local Controls & & & & & & & & \\
\hline Type of housing (PCA axe 1 ) & $\begin{array}{r}-0.019^{* * *} \\
(0.007)\end{array}$ & $\begin{array}{r}-0.043^{* *} \\
(0.019)\end{array}$ & $\begin{array}{r}-0.009 \\
(0.007)\end{array}$ & $\begin{array}{r}-0.021 \\
(0.021)\end{array}$ & $\begin{array}{r}-0.014^{* *} \\
(0.007)\end{array}$ & $\begin{array}{r}-0.030 \\
(0.020)\end{array}$ & $\begin{array}{r}0.017^{* *} \\
(0.008)\end{array}$ & $\begin{array}{l}-0.015 \\
(0.023)\end{array}$ \\
\hline Social composition (PCA axe 2) & $\begin{array}{r}0.031^{* * *} \\
(0.009)\end{array}$ & $\begin{array}{r}0.030 \\
(0.020)\end{array}$ & $\begin{array}{r}0.072^{* * *} \\
(0.011)\end{array}$ & $\begin{array}{r}0.041^{* *} \\
(0.021)\end{array}$ & $\begin{array}{r}0.082^{* * *} \\
(0.011)\end{array}$ & $\begin{array}{r}0.046^{* *} \\
(0.021)\end{array}$ & $\begin{array}{r}0.078^{* * *} \\
(0.011)\end{array}$ & $\begin{array}{c}0.038^{*} \\
(0.021)\end{array}$ \\
\hline Residual axe (PCA axe 3) & $\begin{array}{r}-0.027 * * \\
(0.011)\end{array}$ & $\begin{array}{r}0.045 \\
(0.034)\end{array}$ & $\begin{array}{r}0.009 \\
(0.012)\end{array}$ & $\begin{array}{r}0.038 \\
(0.034)\end{array}$ & $\begin{array}{r}0.008 \\
(0.011)\end{array}$ & $\begin{array}{r}0.045 \\
(0.033)\end{array}$ & $\begin{array}{r}0.013 \\
(0.012)\end{array}$ & $\begin{array}{r}0.045 \\
(0.034)\end{array}$ \\
\hline Intercept & $\begin{array}{r}0.381^{* * *} \\
(0.103)\end{array}$ & & $\begin{array}{r}-0.449^{* *} \\
(0.180)\end{array}$ & & $\begin{array}{r}-0.467^{* * *} \\
(0.159)\end{array}$ & & $\begin{array}{r}-1.841^{* * *} \\
(0.304)\end{array}$ & \\
\hline $\mathrm{N}$ & 26751 & 26751 & 26751 & 26751 & 26,751 & 26,751 & 26,751 & 26,751 \\
\hline
\end{tabular}

Note: Source: Generation surveys (1998 and 2004). Standard errors are in parenthesis. ${ }^{*} p<0.1,{ }^{* *} p<0.05,{ }^{* * *} p<0.01$. Exogenous model (Exo.) was estimated using logit models, and $\$ 7 x e d$ effect estimates(FE) were obtained using a conditional logit models. 


\section{Marginal effect of education}

Table 11: Marginal Effect of Education

\begin{tabular}{|c|c|c|c|c|c|c|c|c|}
\hline & \multicolumn{4}{|c|}{ Employment-Population Ratio } & \multicolumn{4}{|c|}{ Employment Rate } \\
\hline & \multicolumn{2}{|c|}{$15-24$} & \multicolumn{2}{|c|}{$25-64$} & \multicolumn{2}{|c|}{$15-24$} & \multicolumn{2}{|c|}{$25-64$} \\
\hline & Exo. & FE & Exo. & FE & Exo. & FE & Exo. & $\mathrm{FE}$ \\
\hline \multicolumn{9}{|l|}{ All } \\
\hline High-school dropouts & ref. & ref. & ref. & ref. & ref. & ref. & ref. & ref. \\
\hline Short professional tracks & $\begin{array}{r}0.13^{* * *} \\
(0.01)\end{array}$ & $\begin{array}{r}0.13^{* * *} \\
(0.01)\end{array}$ & $\begin{array}{r}0.14^{* * * *} \\
(0.01)\end{array}$ & $\begin{array}{r}0.14^{* * * *} \\
(0.01)\end{array}$ & $\begin{array}{r}0.14^{* * *} \\
(0.01)\end{array}$ & $\begin{array}{r}0.14^{* * * *} \\
(0.01)\end{array}$ & $\begin{array}{r}0.13^{* * * *} \\
(0.01)\end{array}$ & $\begin{array}{r}0.13^{* * *} \\
(0.01)\end{array}$ \\
\hline General high-school & $\begin{array}{r}0.13^{* * *} \\
(0.01)\end{array}$ & $\begin{array}{r}0.13^{* * *} \\
(0.01)\end{array}$ & $\begin{array}{r}0.13^{* * *} \\
(0.01)\end{array}$ & $\begin{array}{r}0.13^{* * *} \\
(0.01)\end{array}$ & $\begin{array}{r}0.13^{* * *} \\
(0.01)\end{array}$ & $\begin{array}{r}0.13^{* * *} \\
(0.01)\end{array}$ & $\begin{array}{r}0.13^{* * *} \\
(0.01)\end{array}$ & $\begin{array}{r}0.13^{* * *} \\
(0.01)\end{array}$ \\
\hline Community college & $\begin{array}{r}0.28^{* * *} \\
(0.01)\end{array}$ & $\begin{array}{r}0.28^{* * *} \\
(0.01)\end{array}$ & $\begin{array}{r}0.29^{* * *} \\
(0.01)\end{array}$ & $\begin{array}{r}0.29^{* * *} \\
(0.01)\end{array}$ & $\begin{array}{r}0.28^{* * *} \\
(0.01)\end{array}$ & $\begin{array}{r}0.28^{* * *} \\
(0.01)\end{array}$ & $\begin{array}{r}0.28^{* * *} \\
(0.01)\end{array}$ & $\begin{array}{r}0.28^{* * *} \\
(0.01)\end{array}$ \\
\hline College & $\begin{array}{r}0.20^{* * *} \\
(0.02)\end{array}$ & $\begin{array}{r}0.20^{* * *} \\
(0.02)\end{array}$ & $\begin{array}{r}0.20^{* * *} \\
(0.02)\end{array}$ & $\begin{array}{r}0.20^{* * *} \\
(0.02)\end{array}$ & $\begin{array}{r}0.20^{* * *} \\
(0.02)\end{array}$ & $\begin{array}{r}0.20^{* * *} \\
(0.02)\end{array}$ & $\begin{array}{r}0.20^{* * *} \\
(0.02)\end{array}$ & $\begin{array}{r}0.20^{* * * *} \\
(0.02)\end{array}$ \\
\hline Higher graduate & $\begin{array}{r}0.25^{* * *} \\
(0.02)\end{array}$ & $\begin{array}{r}0.25^{* * *} \\
(0.02)\end{array}$ & $\begin{array}{r}0.25^{* * *} \\
(0.02)\end{array}$ & $\begin{array}{r}0.25^{* * *} \\
(0.02)\end{array}$ & $\begin{array}{r}0.25^{* * *} \\
(0.02)\end{array}$ & $\begin{array}{r}0.25^{* * *} \\
(0.02)\end{array}$ & $\begin{array}{r}0.24^{* * *} \\
(0.02)\end{array}$ & $\begin{array}{r}0.24^{* * *} \\
(0.02)\end{array}$ \\
\hline $\mathrm{N}$ & 26751 & 26751 & 26751 & 26751 & 26751 & 26751 & 26751 & 26751 \\
\hline \multicolumn{9}{|l|}{ Men } \\
\hline High-school dropouts & ref. & ref. & ref. & ref. & ref. & ref. & ref. & ref. \\
\hline Short professional tracks & $\begin{array}{r}0.14^{* * *} \\
(0.01)\end{array}$ & $\begin{array}{r}0.14^{* * *} \\
(0.01)\end{array}$ & $\begin{array}{r}0.14^{* * *} \\
(0.01)\end{array}$ & $\begin{array}{r}0.14^{* * *} \\
(0.01)\end{array}$ & $\begin{array}{r}0.14^{* * *} \\
(0.01)\end{array}$ & $\begin{array}{r}0.14^{* * *} \\
(0.01)\end{array}$ & $\begin{array}{r}0.14^{* * *} \\
(0.01)\end{array}$ & $\begin{array}{r}0.14^{* * *} \\
(0.01)\end{array}$ \\
\hline General high-school & $\begin{array}{r}0.13^{* * *} \\
(0.02)\end{array}$ & $\begin{array}{r}0.13^{* * *} \\
(0.02)\end{array}$ & $\begin{array}{r}0.13^{* * *} \\
(0.02)\end{array}$ & $\begin{array}{r}0.13^{* * *} \\
(0.02)\end{array}$ & $\begin{array}{r}0.13^{* * *} \\
(0.02)\end{array}$ & $\begin{array}{r}0.13^{* * *} \\
(0.02)\end{array}$ & $\begin{array}{r}0.13^{* * *} \\
(0.02)\end{array}$ & $\begin{array}{r}0.13^{* * *} \\
(0.02)\end{array}$ \\
\hline Community college & $\begin{array}{r}0.22^{* * *} \\
(0.02)\end{array}$ & $\begin{array}{r}0.22^{* * *} \\
(0.02)\end{array}$ & $\begin{array}{r}0.23^{* * *} \\
(0.02)\end{array}$ & $\begin{array}{r}0.23^{* * *} \\
(0.02)\end{array}$ & $\begin{array}{r}0.22^{* * *} \\
(0.02)\end{array}$ & $\begin{array}{r}0.22^{* * *} \\
(0.02)\end{array}$ & $\begin{array}{r}0.22^{* * *} \\
(0.02)\end{array}$ & $\begin{array}{r}0.22^{* * *} \\
(0.02)\end{array}$ \\
\hline College & $\begin{array}{r}0.15^{* * *} \\
(0.03)\end{array}$ & $\begin{array}{r}0.15^{* * *} \\
(0.03)\end{array}$ & $\begin{array}{r}0.15^{* * *} \\
(0.03)\end{array}$ & $\begin{array}{r}0.15^{* * *} \\
(0.03)\end{array}$ & $\begin{array}{r}0.15^{* * *} \\
(0.03)\end{array}$ & $\begin{array}{r}0.15^{* * *} \\
(0.03)\end{array}$ & $\begin{array}{r}0.15^{* * *} \\
(0.03)\end{array}$ & $\begin{array}{r}0.15^{* * * *} \\
(0.03)\end{array}$ \\
\hline Higher graduate & $\begin{array}{r}0.21^{* * *} \\
(0.03)\end{array}$ & $\begin{array}{r}0.21^{* * *} \\
(0.03)\end{array}$ & $\begin{array}{r}0.22^{* * *} \\
(0.03)\end{array}$ & $\begin{array}{r}0.22^{* * *} \\
(0.03)\end{array}$ & $\begin{array}{r}0.21^{* * *} \\
(0.03)\end{array}$ & $\begin{array}{r}0.21^{* * *} \\
(0.03)\end{array}$ & $\begin{array}{r}0.21^{* * *} \\
(0.03)\end{array}$ & $\begin{array}{r}0.21^{* * *} \\
(0.03)\end{array}$ \\
\hline $\mathrm{N}$ & 10507 & 10507 & 10507 & 10507 & 10507 & 10507 & 10507 & 10507 \\
\hline
\end{tabular}

Women

\begin{tabular}{lrrrrrrrr}
\hline High-school dropouts & ref. & ref. & ref. & ref. & ref. & ref. & ref. & ref. \\
Short professional tracks & $0.15^{* * *}$ & $0.15^{* * *}$ & $0.15^{* * *}$ & $0.15^{* * *}$ & $0.15^{* * *}$ & $0.15^{* * *}$ & $0.15^{* * *}$ & $0.15^{* * *}$ \\
& $(0.02)$ & $(0.02)$ & $(0.02)$ & $(0.02)$ & $(0.02)$ & $(0.02)$ & $(0.02)$ & $(0.02)$ \\
General high-school & $0.16^{* * *}$ & $0.16^{* * *}$ & $0.16^{* * *}$ & $0.16^{* * *}$ & $0.16^{* * *}$ & $0.16^{* * *}$ & $0.16^{* * *}$ & $0.16^{* * *}$ \\
& $(0.02)$ & $(0.02)$ & $(0.02)$ & $(0.02)$ & $(0.02)$ & $(0.02)$ & $(0.02)$ & $(0.02)$ \\
Community college & $0.39^{* * *}$ & $0.39^{* * *}$ & $0.40^{* * *}$ & $0.40^{* * *}$ & $0.39^{* * *}$ & $0.39^{* * *}$ & $0.39^{* * *}$ & $0.39^{* * *}$ \\
& $(0.02)$ & $(0.02)$ & $(0.02)$ & $(0.02)$ & $(0.02)$ & $(0.02)$ & $(0.02)$ & $(0.02)$ \\
College & $0.27^{* * *}$ & $0.27^{* * *}$ & $0.28^{* * *}$ & $0.28^{* * *}$ & $0.27^{* * *}$ & $0.27^{* * *}$ & $0.27^{* * *}$ & $0.27^{* * *}$ \\
& $(0.03)$ & $(0.03)$ & $(0.03)$ & $(0.03)$ & $(0.03)$ & $(0.03)$ & $(0.03)$ & $(0.03)$ \\
Higher graduate & $0.34^{* * *}$ & $0.34^{* * *}$ & $0.34^{* * *}$ & $0.34^{* * *}$ & $0.33^{* * *}$ & $0.33^{* * *}$ & $0.33^{* * *}$ & $0.33^{* * *}$ \\
& $(0.03)$ & $(0.03)$ & $(0.03)$ & $(0.03)$ & $(0.03)$ & $(0.03)$ & $(0.03)$ & $(0.03)$ \\
\hline $\mathrm{N}$ & 10874 & 10874 & 10874 & 10874 & 10874 & 10874 & 10874 & 10874
\end{tabular}

Note: Source: Generation surveys (1998 and 2004). All estimations include controls for education, age, past mobility, living arrangement, and parental characteristics. Standard errors are in parenthesis. $* p<0.1, * *$ $p<0.05,{ }^{* * *} p<0.01$ Column names indicate the rate used as explanatory variable. Exogenous model (Exo.) was estimated using logit models, and Fixed effect estimates(FE) were obtained using a conditional logit models. In the case of FE models, marginal effects were obtained by fixing the unobserved heterogeneity term to 0 . 


\section{References}

Aeberhardt, R., Rathelot, R. and Safi, M. [2015], 'Les difficultés scolaires et professionnelles des jeunes issus de l'immigration : effet de l'origine ou effets géographiques ?', Population 70(3), 599-635.

Akerlof, G. A. [1997], 'Social Distance and Social Decisions', Econometrica: Journal of the Econometric Society 65(5), 1005-1027.

Altonji, J. G., Kahn, L. B. and Speer, J. D. [2014], Cashier or consultant? entry labor market conditions, field of study, and career success, Working Paper 20531, National Bureau of Economic Research.

Andersson, F., Burgess, S. and Lane, J. [2014], 'Do as the neighbors do: Examining the effect of residential neighborhoods on labor market outcomes', Journal of Labor Research 35(4), 373392.

Arrow, K. J. [1973], The theory of discrimination, in O. Ashenfelter and A. Rees, eds, 'Discrimination in Labor Markets', Princeton University Press, pp. 3-33.

Arulampalam, W., Booth, A. L. and Taylor, M. P. [2000], 'Unemployment persistence', Oxford Economic Papers 52(1), 24-50.

Bayer, P., Ferreira, F. and McMillan, R. [2007], 'A unified framework for measuring preferences for schools and neighborhoods', Journal of Political Economy 115(4), 588-638.

Bayer, P., Ross, S. L. and Topa, G. [2008], 'Place of work and place of residence: Informal hiring networks and labor market outcomes', Journal of Political Economy 116(6), 1150-1196.

Bernheim, B. D. [1994], ‘A theory of conformity', Journal of political Economy pp. 841-877.

Briant, A., Lafourcade, M. and Schmutz, B. [2015], 'Can tax breaks beat geography? Lessons from the french enterprise zone experience', American Economic Journal: Economic Policy $7(2)$.

Brock, W. A. and Durlauf, S. N. [2001], 'Discrete choice with social interactions', Review of Economic Studies 68(2), 235-60. 
Brock, W. A. and Durlauf, S. N. [2007], 'Identification of binary choice models with social interactions', Journal of Econometrics 140(1), 52-75.

Cahuc, P., Carcillo, S., Rinne, U. and Zimmermann, K. F. [2013], 'Youth unemployment in old europe: the polar cases of france and germany', IZA Journal of European Labor Studies 2(1), 18 .

URL: http://dx.doi.org/10.1186/2193-9012-2-18

Calvo-Armengol, A. and Jackson, M. O. [2004], 'The effects of social networks on employment and inequality', American Economic Review 94(3), 426-454.

Chamberlain, G. [1980], 'Analysis of Covariance with Qualitative Data', Review of Economic Studies 47(1), 225-38.

Clark, A. E. [2003], 'Unemployment as a social norm: Psychological evidence from panel data', Journal of Labor Economics 21(2), pp. 323-351.

Cliff, A. and Ord, J. [1981], Spatial Processes: Models \& Applications, Pion.

URL: https://books.google.co.uk/books?id=MiOOAAAAQAAJ

Crane, J. [1991], 'The epidemic theory of ghettos and neighborhood effects on dropping out and teenage childbearing', American Journal of Sociology 96(5), 1226-1259.

Dahl, G. B. [2002], 'Mobility and the return to education: Testing a roy model with multiple markets', Econometrica 70(6), 2367-2420.

Damm, A. P. [2014], 'Neighborhood quality and labor market outcomes: Evidence from quasirandom neighborhood assignment of immigrants', Journal of Urban Economics 79, 139-166.

Dujardin, C. and Goffette-Nagot, F. [2010], 'Neighborhood effect on unemployment? a test à la altonji', Regional Science and Urban Economics 40(6).

Duncan, O. D. and Duncan, B. [1955], 'A methodological analysis of segregation indexes', American sociological review 20(2), 210-217.

Eurostat [2016], 'Euro area unemployment rate at 10.5\%', News release Euro indicators, 7 January. 
Gobillon, L. and Selod, H. [2014], Spatial mismatch, poverty, and vulnerable populations, in M. M. Fischer and P. Nijkamp, eds, 'Handbook of Regional Science', Springer, pp. 93-107.

Gobillon, L., Selod, H. and Zenou, Y. [2007], 'The mechanisms of spatial mismatch', Urban Studies 44(12), 2401-2427.

Godinot, A. [2014], Redesigning the french population census, Courrier des statistiques 10, INSEE.

Goux, D. and Maurin, E. [2007], 'Close neighbours matter: Neighbourhood effects on early performance at school', The Economic Journal 117(523), 1193-1215.

Granovetter, M. S. [1973], 'The strength of weak ties', American journal of sociology pp. 13601380.

Gregg, P. [2001], 'The impact of youth unemployment on adult unemployment in the ncds', The economic journal 111(475), 626-653.

Grinblatt, M., Keloharju, M. and Ikäheimo, S. [2008], 'Social influence and consumption: Evidence from the automobile purchases of neighbors', The Review of Economics and Statistics 90(4), 735-753.

URL: $h t t p: / / w w w . j s t o r . o r g / s t a b l e / 40043111$

Hellerstein, J. K., Kutzbach, M. J. and Neumark, D. [2014], 'Do labor market networks have an important spatial dimension?', Journal of Urban Economics 79, 39-58.

Hellerstein, J. K., McInerney, M. and Neumark, D. [2011], 'Neighbors and coworkers: The importance of residential labor market networks', Journal of Labor Economics 29(4), 659695.

Holzer, H. J. [1988], 'Search methods used by unemployed youth', Journal of Labor Economics 6(1), 1-20.

Hémet, C. and Malgouyres, C. [2016], 'Diversity and Employment Prospects: Neighbors Matter!', CEPR Discussion Papers (11396).

Ihlanfeldt, K. R. and Sjoquist, D. L. [1991], 'The effect of job access on black and white youth employment: a cross-sectional analysis', Urban Studies 28(2), 255-265. 
INSEE [2016], Tableaux de l'économie française, édition 2016, INSEE Références.

International Labor Organization [2012], Global employment trends for youth 2012, Report, International Labor Organization.

Ioannides, Y. M. [2011], Chapter 25 - neighborhood effects and housing, Vol. 1 of Handbook of Social Economics, North-Holland, pp. $1281-1340$.

Ioannides, Y. M. and Loury, L. D. [2004], 'Job information networks, neighborhood effects, and inequality', Journal of Economic Literature 42(4), 1056-1093.

Ioannides, Y. M. and Topa, G. [2010], 'Neighborhood effects: Accomplishments and looking beyond them', Journal of Regional Science 50(1), 343-362.

Kain, J. F. [1968], 'Housing segregation, negro employment, and metropolitan decentralization', Quarterly Journal of Economics 82(2), pp. 175-197.

Kain, J. F. [2004], 'A pioneer's perspective on the spatial mismatch literature', Urban Studies 41(1), 7-32.

Kamionka, T. and Ngoc, X. V. [2016], 'Insertion des jeunes sur le marché du travail, diplôme et quartier d'origine: une modélisation dynamique', Revue économique 67(3), 463-494.

Kramarz, F. and Skans, O. N. [2014], 'When strong ties are strong: Networks and youth labour market entry', The Review of Economic Studies 81(3), 1164-1200.

Lancaster, T. [2000], 'The incidental parameter problem since 1948', Journal of Econometrics 95(2), $391-413$.

Manski, C. F. [1993], 'Identification of endogenous social effects: The reflection problem',

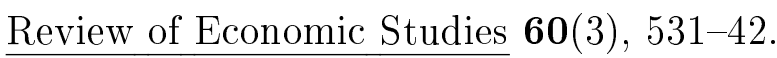

Maurin, E. and Moschion, J. [2009], 'The social multiplier and labor market participation of mothers', American Economic Journal: Applied Economics 1(1), 251-72.

URL: http://www.aeaweb.org/articles?id=10.1257/app.1.1.251

Mota, N., Patacchini, E. and Rosenthal, S. S. [2016], 'Neighborhood Effects, Peer Classification, and the Decision of Women to Work', IZA Discussion Paper 9985. 
Nicoletti, C., Salvanes, K. G. and Emma, T. [2016], 'The family peer effect on mothers' labour supply', IZA Discussion Paper 9927.

Oreopoulos, P., von Wachter, T. and Heisz, A. [2012], 'The short- and long-term career effects of graduating in a recession', American Economic Journal: Applied Economics 4(1), 1-29.

Özgür, O. [2011], Chapter 13 - local interactions, Vol. 1A of Handbook of Social Economics, North-Holland, pp. $587-644$.

Patacchini, E., Picard, P. M. and Zenou, Y. [2015], 'Urban social structure, social capital and spatial proximity', Working Paper .

Sari, F. [2012], 'Analysis of neighborhood effects and work behaviour: Evidence from paris', Housing Studies 27(1), 45-76.

Solignac, M. and Tô, M. [2016], 'Le niveau de chômage dans le voisinage affecte-t-il l'entrée sur le marché du travail ?', Revue économique 67 (3), 495-524.

Stutzer, A. and Lalive, R. [2004], 'The role of social work norms in job searching and subjective well-being', Journal of the European Economic Association 2(4), 696-719.

Topa, G. and Zenou, Y. [2015], Neighborhood versus network effects, in G. Duranton, V. Henderson and W. Strange, eds, 'Handbook of Regional and Urban Economics', Elsevier Publisher, pp. 93-107.

Waldinger, R. [2015], The Cross-Border Connection. Immigrants, Emigrants, and Their Homelands, Harvard University Press.

Weinberg, B. A., Reagan, P. B. and Yankow, J. J. [2004], 'Do neighborhoods affect hours worked? evidence from longitudinal data', Journal of Labor Economics 22(4), 891-924.

Zenou, Y. and Boccard, N. [2000], 'Racial discrimination and redlining in cities', Journal of Urban Economics (48), 260-285. 